\title{
Global Firms and Global Sheriffs? Why Territory Matters for Extraterritorial Enforcement of Regulatory Regimes*
}

\author{
Lorenzo Crippa ${ }^{\dagger}$
}

October 5, 2021

Word count: 12701

\begin{abstract}
International regimes demand states regulate private companies to ensure better governance of markets. Although global firms can evade regulations creating complex ownership structures, a few countries enforce their laws extraterritorially. They can prosecute firms regardless of their nationality, behaving as "global sheriffs". However, these countries only prosecute a fraction of the foreign firms under their jurisdiction. This variation remains largely unexplained. I study this phenomenon focusing on US prosecution of foreign companies. I argue that US authorities are more likely to prosecute companies with US investment. Formally, this is no requirement for the application of American extraterritorial regulations. Yet, when a company invests in the US it establishes jobs, branches, and business that make it visible to the local public opinion. US prosecutors exploit reputational risk induced by such exposure to obtain cooperation by the firm and retrieve necessary information to build a case. I test my argument using novel firm-level data on enforcement of policies under the anti-bribery regime and on non-US companies' US investment. The probability that US authorities investigate a suspect foreign company increases by 0.26 when it has investment in the US. Thus, even powerful extraterritorial regulators need a territorial leverage to rule on foreign multinationals.
\end{abstract}

Keywords: Regulatory regimes; Extraterritoriality; Multinational corporations; Anti-bribery

*Versions of this paper were circulated at the University of Essex IR PhD colloquium, International Corruption Research Network 2021 Forum, EPSA 2021, APSA 2021. The paper received great feedback from many great minds. I am thankful to each one of them. In alphabetic order: Nicole Baerg, Maria Crippa, Franziska Deeg, Han Dorussen, Felix Goldberg, Federica Genovese, Carolina Moehlecke, Stoyan Panov, Brian Phillips, Sara Polo, Laura Saavedra-Lux, Martin Steinwand, Yannick Stiller, Calvin Thrall, Stefanie Walter. I also warmly thank Phil Swatton for helping me set up the web-scraping data collection. All remaining mistakes are mine.

${ }^{\dagger}$ PhD student, Department of Government, University of Essex. 1.crippa@essex.ac.uk 


\section{Introduction}

Sovereign states solve problems of collective action in an anarchic international arena by creating international regimes (Keohane, 1984). Regimes have evolved with the global economy. Early ones were aimed at negotiating a retreat of states from global markets ${ }^{1}$ (Strange, 1996). After the 1990s, yet, a new kind of transnational governance emerged. States started negotiating rules upon multinational firms and their supply chains to advance environmental, social, and governance (ESG) values (Vogel, 1997). Examples include anti-trust, taxation, environmental agreements, labor and human rights protection, criminalization of money laundering, and anti-bribery. Global firms often fragment their ownership structure across borders to evade regulations (Arel-Bundock, 2017; Chapman et al., 2020) or exploit advantageous conditions they create (Genovese, 2020; Thrall, 2021). This begs the question: are states condemned to be helpless in face of such regulatory arbitrage?

On the contrary, a few countries have adopted policies to prosecute foreign multinational corporations (MNCs) as if they were domestic, acting as "global sheriffs" of regulatory regimes. The current champion of this approach to regulatory enforcement is the US (Putnam, 2009). Each year American prosecutors levy billions of dollars in fines for corporate crimes committed by non-US companies around the world. Such broad extraterritorial approach to regulatory enforcement makes the US arguably the most relevant judicial regulator of multinational corporations. It is also key to further ESG values in a world where cross-border nefarious transactions are ever more complex (Cooley and Sharman, 2017) and other countries' regulatory efforts are often weak (Brewster, 2014). Others have attempted to follow the US example (Kaczmarek and Newman, 2011), albeit with more modest success (Crasnic et al., 2017).

Yet, these "global sheriffs" do not appear to be enforcing their laws against all cases they could prosecute (Ruggie, 2018). What makes a country behave as a "global sheriff" and enforce its regulations against a foreign company? This question hinges on the nature of power in transnational economic governance. Political science and international relations scholarships have dedicated scant attention to the sources of extraterritorial enforcement, despite its relevance for contemporary regulatory regimes (Putnam, 2009). The lack of clear data on cases that authorities could have prosecuted exacerbates the problem. As a result, the question is left substantively unanswered and vulnerable to claims by corporate practitioners that judicial authorities select foreign firms so as to favor national companies ${ }^{2}$.

In the paper I set to study what explains selection of foreign companies to prosecute under extraterritorial regulatory regimes. I argue that prosecutors gain a leverage to rule over a foreign firm depending on its investment in their economy. Global firms need not be physically present in a country to be formally

\footnotetext{
${ }^{1}$ This was particularly true for commercial regimes. For instance, rounds at the General Agreements on Tariffs and Trade were usually aimed at negotiating a lift of unilateral trade barriers, like tariffs.

${ }^{2}$ See a book by Pierucci (2019), former manager to the French Alstom, who denounces the relentless approach of US judicial authorities against non-US companies, allegedly aimed at favoring US competitors. The book has recently become a best-selling phenomenon in China: https://www.washingtonpost.com/world/2019/06/07/ an-unlikely-winner-china-us-trade-war-french-businessmans-book-about-his-battle-with-doj/.
} 
subject to its extraterritorial regulations. A marginal connection is usually sufficient for authorities to establish extraterritorial jurisdiction on corporate wrongdoing ${ }^{3}$. Yet, when a foreign company invests in a country it creates jobs, business, and activities that expose it to the public opinion. In comparison to foreign firms with no investment, one that invests is a well-visible entity. This induces a larger reputational damage for the parent company in the host country, in case scandals for corporate crime emerged (Karpoff et al., 2008). Companies attempt to minimize such damage by signalling compliance through cooperation with prosecutors (Garrett, 2014). Cooperation gives prosecutors access to necessary information and documents to bring on a corporate case. Thus, territorial presence of a company in their country facilitates prosecutors' extraterritorial job and construction of a case against a foreign corporate defendant. In other words, I claim that extraterritoriality is a viable regulatory strategy only when authorities have a territorial leverage to play.

I test this argument studying US prosecution of non-US companies for events of bribery. The American case is ideal for theoretical, methodological, and empirical reasons. Theoretically, the US is a least-likely case to test my argument. If territorial presence is necessary for extraterritoriality of a powerful country like the US, the argument likely applies to weaker regulators as well. Moreover, US prosecutors enjoy substantial freedom in their choice of cases to investigate (Tomashevskiy, 2021). Territoriality is not a jurisdictional requirement for the application of extraterritorial American law (Leibold, 2014). Cooperation between corporate defendants and authorities is also the standard in the US system ${ }^{4}$. Hence, US regulators would have the prerogatives and power to do their job without necessarily relying on territoriality to build a case. Methodologically, focusing on explaining prosecution by a single country holds constant legal features that vary across countries and that pertain to the de jure extraterritorial authority, rather than to its de facto application. Finally, and from an empirical perspective, the US shows surprising variation in its efforts to prosecute foreign companies for anti-bribery violations. It is arguably the most vigorous extraterritorial enforcer of corporate regulations ${ }^{5}$. Yet, each year it prosecutes only a handful of the foreign companies it has jurisdiction on (Garrett, 2011).

The choice to study the anti-bribery regime allows to overcome the obvious problem that we can only observe cases that US authorities enforced. We are not able to observe the universe of enforceable cases that federal agencies chose not to consider. This prevents to explain selection of cases and condemns recent studies on the matter to focus only on explaining size of penalties imposed by US agencies on

\footnotetext{
${ }^{3}$ Extraterritoriality is usually supported by legal principles such as the "effects doctrine" - stating that misconduct by foreign subjects occurring abroad may be regulated by a state because of its effects on interests within the domain of the state - or the "presence doctrine" - stating that misconduct by foreign subjects occurring abroad may be regulated by a state if the misbehavior is partly in connection to its territorial domain. The United States has traditionally proposed a very broad interpretation of these principles, and de facto exercised its authority on economic crimes with a very marginal connection to the US economy (Leibold, 2014).

${ }^{4}$ Companies usually settle charges with authorities avoiding perils of a trial. Legal instruments used include nonprosecution agreements (NPAs) and deferred prosecution agreements (DPAs), see Garrett (2014).

${ }^{5}$ For instance, the original dataset supporting this study shows the US has enforced about half of all extraterritorial anti-bribery actions. The next two countries in line are the United Kingdom and Switzerland, accounting respectively for about $9.81 \%$ and $4.15 \%$ of total cases.
} 
companies conditional on cases that were enforced (Choi and Davis, 2014; Tomashevskiy, 2021).

I propose a way around the problem leveraging on two unique features of the US-sponsored international anti-bribery regime. First, the regime has diffused US-like anti-bribery policies to member states, that are now mandated to prohibit their MNCs from paying bribes to foreign public officials in international transactions (Bukovansky, 2006). Thus, a larger set of cases is observable involving non-US companies in violation of US-like anti-corruption policies around the globe, not necessarily prosecuted by the US. Second, the regime strengthened US capacity to enforce its own extraterritorial policy (Brewster, 2014). Because of that, virtually all observable anti-bribery cases under this regime umbrella were in principle prosecutable by US authorities, who need only a marginal connection of the defendant non-US company to their economy to claim jurisdiction (Kaczmarek and Newman, 2011; Leibold, 2014).

I leverage these characteristics and construct a novel dataset composed of observable events where non-US companies violated the anti-bribery regime, by (allegedly) paying or offering bribes to foreign public officials. I extract data from reports in the TRACE International Compendium, a collection of documents summarising legal anti-bribery actions involving MNCs from around the world. I use automated techniques for scraping the information from this source. I cross-check and complement my dataset with several providers of legal data on anti-bribery actions. I explore this dataset and explain why the US investigated about $40 \%$ of non-US companies involved in corporate bribery scandals in my dataset $^{6}$. I argue that American prosecutors are more likely to enforce anti-bribery policies against a foreign parent firm when it sets up a subsidiary in the US, even though their formal authority to do so does not strictly depend on investments in the US domestic economy.

To test my argument, I merge my novel dataset with firm-level information on corporate ownership and cross-border investment. A selection on observables design shows that the probability of being investigated by American authorities for companies involved in anti-bribery scandals increases by about 0.26 for companies with investments in the US, when holding constant important sources of confounding. A sensitivity analysis provides concrete reference points for the assumption of no omitted variable bias. It provides confidence that unobserved confounders are unlikely to be in place.

The article is structured as follows. I first expand on the puzzle motivating the study. Next, I present my argument for the impact of corporate ownership on states' extraterritorial capacity. I do so discussing incentives and constraints for judiciary authorities and MNCs in extraterritorial corporate prosecution. A presentation of the anti-bribery regime and the role US prosecutors play in it follows. Here, I derive testable hypotheses from my argument to explain US extraterritorial anti-bribery enforcement. I then introduce my research design to test such hypotheses. I introduce the novel data used and my research strategy. Next, I present my findings and discuss them.

\footnotetext{
${ }^{6}$ Original computation based on the dataset used in the article.
} 


\section{Extraterritorial enforcement of international regulatory regimes}

International regimes are more or less formalized institutional arrangements pertaining to the same issue area. Countries employ them to coordinate their behavior (Keohane, 1984). Whereas with earlier regimes sovereign states negotiated mutual constraints on their behaviors, regulatory regimes developed since the 1990s have been aimed at negotiating common rules on international markets. Negative externalities of global production and large corporate scandals became more frequent in this decade. Examples of multinational corporations violating labor and human rights, or involved in corruption, financial crime, and environmental damage made countries recognize that they needed to agree on common corporate rules to constrain global firms, if they were to foster ESG values in a complex global economy (Abbott and Snidal, 2002; Cooley and Sharman, 2017). One of the key mechanisms supporting these regimes is the threat of judiciary repercussions at home for firms that violate ESG standards abroad.

States are ultimately responsible for the effectiveness of such regimes through their enforcement (Baradaran et al., 2012; Simmons, 2010). The literature posits two key problems are in the way of effective regime enforcement. First, although regulatory regimes do not necessarily penalize companies (Crippa, 2021), transnational firms can fragment ownership structures and supply chains across borders to evade regulations (Arel-Bundock, 2017; Chapman et al., 2020; Fisman et al., 2008) or to profit from the conditions they create (Genovese, 2020; Thrall, 2021). Second, self-interested states can defect from their obligations to prosecute foreign corporate crime by their nationals, if they do not bear its negative externalities $^{7}$ (Eilstrup-Sangiovanni and Sharman, 2019; Hafner-Burton and Schneider, 2019).

A vibrant debate has then emerged to study if, net of these two problems, enforcement of international regimes is effective. Mixed evidence exists on the efficacy of enforcement. Some studies find that it successfully reduces transnational corruption (Jensen and Malesky, 2018), others provide concerning evidence on the lack of effectiveness against financial crimes (Findley et al., 2015). Many conclude formal state-based law cannot hold private actors accountable for misconduct along cross-border supply chains (Ruggie, 2018). If so, they continue, the only feasible tool to hold corporations accountable for transnational misbehavior could be in the hands of a global civil society, which could punish market actors when information on their misconduct arises (Kreitmeir et al., 2020).

I contend that, by assuming these two problems represented the key issues of regulatory regime enforcement, this important literature in political science has overlooked a prerogative of states that potentially overcomes them both: extraterritoriality. States do not only enforce their regulations on national firms for violating ESG principles abroad. In fact, a few powerful countries apply their policies on foreign subjects as well, effectively behaving as "global sheriffs" of a regime ${ }^{8}$ (Slaughter, 2004). The

\footnotetext{
${ }^{7}$ For instance, investigations on alleged bribery of Saudi Arabian officials by the British corporation BAE Systems were repeatedly halted by the UK Government, due to national interest concerns (Gilbert and Sharman, 2016).

${ }^{8}$ The phenomenon is not limited to economic and corporate regulation, as it extends to measures like extradition for non-economic foreign criminal behavior. Nevertheless the focus of this article is solely economic corporate crime.
} 
country that currently champions such extraterritorial approach to enforcement is the United States ${ }^{9}$ (Putnam, 2009). Effectively, its authorities enforce US corporate policies against firms from all over the world and threaten repercussions in the US for violating ESG principles (Garrett, 2011). US authorities have occasionally even used this as a tool to sanction foreign countries (Tomashevskiy, 2021).

Extraterritoriality potentially overcomes the two key obstacles to regulatory regime enforcement. First, to the extent that the net cast by a country is sufficiently large, it can effectively prevent evasion of transnational supply chains from regulatory regimes, as nationality is no obstacle to extraterritorial enforcement. Second, it prevents the hurdle represented by states' self-interest. If it is national interest that causes political intrusions and halts regime enforcement, it appears a "global sheriff" has no reasonable incentive to shield foreign companies for violating ESG principles ${ }^{10}$.

Yet, extraterritoriality is far from being the norm in regulatory regime enforcement ${ }^{11}$. First, only a few countries have adopted instruments to prosecute foreign companies. Differences from this point of view are generally explained because of legal obstacles or technological limitations (Eilstrup-Sangiovanni and Sharman, 2019). Second, countries enforcing regulations extraterritorially show striking variation in their capacity to behave as such. The US only prosecutes a handful of foreign companies each year under each of its corporate regulations, a number which is significantly below that of potential cases it has jurisdiction on (Garrett, 2011). Figure 1 shows that foreign companies are significantly underrepresented in the set of cases prosecuted by the US DOJ, although fines extracted from these companies tend to be higher than those from domestic corporations. When it comes to allegations for certain crimes by MNCs, including human rights violations, these numbers drop significantly (Kreitmeir et al., 2020; Ruggie, 2018).

What gives a country the capacity to behave as a "global sheriff" and enforce a regulatory regime against a certain foreign company? We still know too little to answer this question, despite its relevance for the literature on international regimes. Political science and its sub-disciplines have dedicated surprisingly scant attention to extraterritoriality ${ }^{12}$. International law has studied the issue more extensively. Legal scholars generally conclude that the gap between potential cases and those that are actually enforced is due to the costs and complexity of embarking on cross-border prosecutions (Brewster, 2014). From a political science perspective this is only a partial explanation, however, as it does not justify why legal resources are devoted to the selection of a specific case over another.

\footnotetext{
${ }^{9}$ Examples of US extraterritorial corporate regulations include (but are not limited to) corrupt exchanges, violations of unilateral trade sanctions, taxes on foreign-owned assets, data usage, intellectual property.

${ }^{10}$ If anything critics of the extraterritorial application of US corporate law contend quite the opposite: that American authorities unfairly apply their regulations with disproportionate energy against foreign companies, to alter the playing field of international economic competition and ultimately favor US companies (Leibold, 2014). As an example of such claims, see: "À qui profite la lutte anticorruption? Le piège General Electric", Le Monde Diplomatique, September 2019: https://www.monde-diplomatique.fr/2019/09/A/60335.

${ }^{11}$ I suspect that the reticence of political science to address the topic can be partially justified precisely because extraterritoriality is rather the exception in corporate governance than the rule (Ruggie, 2018). I believe this is yet one more reason making a study about the sources of extraterritorial capacity a relevant contribution.

${ }^{12}$ This literature has rather focused on its effects, see Efrat and Newman (2016) or Kaczmarek and Newman (2011).
} 
Figure 1: Corporate fines levied (a) and number of prosecuted cases (b) from the US DOJ by nationality of indicted firm, $2000-2020$.
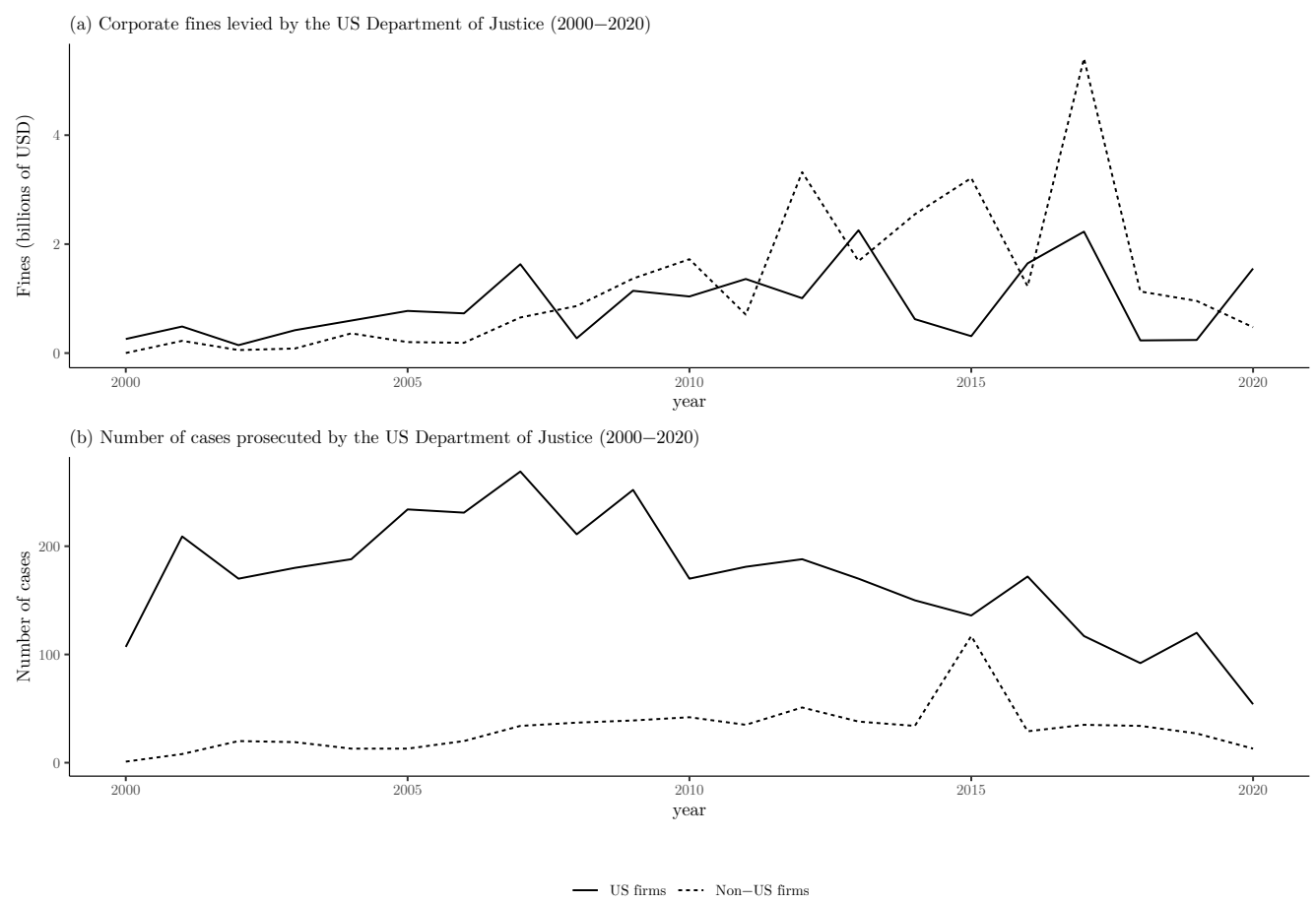

Data retrieved from the Corporate Prosecution Registry (Garrett and Ashley, 2019).

Two potential explanations are provided by the few political science studies on the matter. Putnam (2009) is among the first to address the topic in political science. She argues that the US intervenes extraterritorially when foreign ESG violations undermine the integrity of American domestic norms. Although more satisfactory, not even this claim is able to explain what determines the selection of a company over another that violated the same US domestic norm. Some corporate practitioners contest these decisions are in fact political and are made to advantage US companies in key industrial sectors (Pierucci, 2019).

A second explanation comes from proponents of the so-called "weaponized interdependence" argument. This theory claims countries can leverage transnational economic networks to gain advantage over rival nations and coerce them (Farrell and Newman, 2019). Next section presents an argument that largely builds on insights from this theoretical framework. I draw from there the notion that economic interdependence creates the conditions for countries to exercise their regulatory prerogatives. Yet, I claim this is not done in pursuit of national interest. In fact, I contend it is purely the result of career and professional incentives to bureaucrats in charge of regime enforcement. My argument focuses on the United States case and considers the two key actors of extraterritorial regime enforcement: global firms and national prosecutors. It leads to re-appreciate the role of territory in extraterritorial regulation. 


\section{Global firms and global sheriffs}

Imagine two very similar non-US companies, Red Apple Cigarettes and Morley Cigarettes, were suspected of violating some US extraterritorial corporate policy in a certain foreign country. Whereas Red Apple has a local US subsidiary, American Red Apple, Morley is only publicly traded on the New York Stock Exchange. Besides that, it has no significant presence in the United States. In this fictitious case, the US has the legal authority to rule over both misconducts. Yet, it is not obvious that federal authorities will investigate both companies. The question is: will US authorities be more likely to enforce their policies against either of the two? I argue that corporate ownership empowers state authorities to behave extraterritorially, making Red Apple a more likely target of US courts. Although formal extraterritorial authority typically does not depend on the physical presence of a firm in a country, I argue that states can leverage the investment of a foreign firm within their territory to gain the de facto capacity to behave as "global sheriffs" and prosecute it.

In a nutshell, my argument assumes that judicial authorities have incentives for bringing cases against foreign companies, but they are constrained by limited resources. Therefore, they must focus on cases for which the likelihood to succeed is higher. Probability of success, in turn, depends on availability of information. My claim is that foreign firms with an investment in the prosecutors' economy represent an easier case to investigate than those with no such physical presence, because they have a larger incentive to cooperate with prosecutors and provide information. The reason is that they risk a much larger reputational damage for violating local corporate policies, due to their exposure to the prosecutors' economy. By cooperating with authorities they can minimize such damage and signal compliance to the public opinion. In other words, the opportunity cost of non-cooperation (and, crucially, non-provision of information) for companies with a foot on prosecutors' soil is much higher. Cooperation provides crucial information to agencies, makes such cases easier to win, and affects the selection authorities make.

\subsection{Global sheriffs: Incentives to prosecute and resource constraints}

My argument assumes judicial authorities have incentives for enforcing laws against foreign corporate defendants. This is a reasonable premise: prosecutors have individual-level incentives of monetary and prestige nature to prosecute foreign firms. Successful officers often build thriving careers from winning corporate $\operatorname{cases}^{13}$ (Choi and Pritchard, 2018; DeHaan et al., 2015). The resonance of these cases also benefits them in prestige, building their reputation of tough opposers of economic crime. Corporate scandals regularly make it to the first pages of newspapers and attract the attention of news outlets around the world. They often involve big companies with vast activities across borders, large sums of

\footnotetext{
${ }^{13}$ To provide a few anecdotes, prior to his 2016 appointment as chief of the DOJ Fraud Section, Daniel Kahn had been the lead prosecutor of cases among the top anti-bribery enforcement actions in the US against foreign entities (See: https://fcpablog.com/2016/06/02/doj-names-permanent-chief-of-fcpa-unit/). His subordinates at the Fraud Section share similar successful stories. After a successful experience as a line prosecutor at the DOJ, Albert Stieglitz was seconded overseas, to the UK Serious Fraud Office (See his biography: https://www.pli.edu/faculty/albert--stieglitz-32298).
} 
dirty money mobilized, and vast rents illicitly extracted. On top of this, the blatantly absurd way these resources are sometimes spent makes for eye-catching stories ${ }^{14}$.

Cases against companies are relatively easier to win than those against individuals ${ }^{15}$ (Garrett, 2014), thus they provide a particularly good career opportunity to prosecutors. Reputational damage arising from corporate scandals is a serious concern to companies, which typically accept guilt and try settling allegations without going to court, so as to minimize the time spent under the spotlight of the public opinion. In the US system, pre-trial legal instruments allowing this outcome include deferred prosecution (DPA) or non-prosecution agreements (NPA). These costly solutions expedite the resolution of corporate legal matters. They are based on the idea of avoiding a "death sentence" for a company (Alexander and Arlen, 2018; Garrett, 2018): they prevent perils of judiciary prosecution for the firm, but involve large costs. This solution is precluded to individuals, who also have incentives to go through lengthy trials and appeals in order to maximize their chances of resulting innocent (Davis, 2019).

Prosecutors also have office-level incentives to enforce their laws against foreign corporations, pertaining to their budget. Offices in charge of enforcing corporate criminal laws are public bodies. Budget decisions are thus usually political. Fines and monetary settlements levied are partly employed to compensate those who suffered from the economic crime, but a large share typically ends up in the national Treasury, particularly when victims are hard to identify (Turk, 2012). Zeal of prosecutors' offices thus increases revenues for a government and signals to those in charge of budget decisions that the office is of strategic importance.

Empirical evidence shows that cases against foreign companies tend to be much more remunerative. Fines levied by the US DOJ from foreign corporations tend to be significantly higher than those from domestic corporations ${ }^{16}$. In the case of foreign bribery, with the sole exception of Goldman Sachs, the top 10 monetary corporate settlements for bribery with US agencies have all been paid by non-US entities $^{17}$. Such zeal and surge in revenues is rewarded by governments. In the US the increase in antibribery revenues has paralleled the expansion of prosecutors' offices and the establishment of divisions specialized in the investigation and enforcement of this particular corporate criminal offence.

Therefore, in the example presented above, US prosecutors have a clear incentive for enforcing their laws against both Red Apple Cigarettes and Morley. Yet, prosecutors must focus only on cases where

\footnotetext{
${ }^{14}$ Corrupt corporate money was allegedly used by Malaysian public officials to fund part of the production of Martin Scorsese's movie "The Wolf of Wall Street", ironically enough - see: https://www.theguardian.com/business/ 2019/dec/19/goldman-sachs-close-to-2bn-settlement-over-1mdb-scandal-malaysia -, and in Equatorial Guinea to buy an iconic crystal-studded glove once owned by Michael Jackson - see : https://abcnews.go.com/Blotter/ doj-seeks-jackson-glove-dictators-son/story?id=14812081.

${ }^{15}$ Former FBI director James Comey referred to the DOJ as the "Chickenshit Club" precisely for an alleged tendency to prosecute easier corporate cases rather than more complex individual ones. See: https://www.ft.com/content/ $102 f f a 00-5 b f 4-11 e 7-9 b c 8-8055 f 264 a a 8 b$

${ }^{16}$ Data from Garrett and Ashley (2019) (plotted in Figure 1) reveal that the average fine imposed by the DOJ on a US corporation is $\$ 5,192,672$ whereas that imposed on a non-US company is $\$ 38,368,610$. The difference is highly statistically significant (p-value: $\left.7.6 \times 10^{-9}\right)$.

${ }^{17}$ See the top 10 monetary settlements from the FCPA blog: https://fcpablog.com/2020/10/26/ wall-street-bank-earns-top-spot-on-fcpa-blog-top-ten-list/.
} 
the likelihood of success is higher, because foreign prosecution is a costly endeavour and resources to initiate these cases are scarce (Brewster, 2014). Each year sees prosecutors bringing only a handful of cases against foreign companies, as panel $\mathrm{b}$ in figure 1 shows. When broken down to the various types of corporate offences, this figure is reduced to just a few cases $^{18}$.

The most valuable resource prosecutors need is information on the alleged misconduct, and access to financial records or corporate documents. Authorities from the headquarter of the foreign company usually offer support thanks to multilateral legal assistance (MLA) networks (Brewster, 2014; Kaczmarek and Newman, 2011). Yet, it is cooperation with indicted companies themselves that proves crucial to a case (Baer, 2018; Davis, 2019). Cooperation of defendants is usually mandated by the NPA or DPA program a suspect firm enters. Among the steps of these programs, the firm usually sets up internal investigations on the alleged misconduct. Authorities retrieve relevant information and classified documents from such type of cooperation.

\subsection{Global firms: Incentives to cooperate with prosecutors}

I argue that foreign firms with an investment in the prosecutors' economy have a larger incentive to offer cooperation and provide information to authorities than those with no such physical presence. Information provided makes cases involving these companies easier to win for prosecutors, thus making it more likely that they will be selected over others. Such greater incentive to cooperate depends on the larger reputational damage these companies suffer for a scandal. Evidence shows that firms respond to costs associated with corporate prosecution (Jensen and Malesky, 2018). Firms suffer serious financial consequences when their ESG reputation is undermined (Capelle-Blancard and Petit, 2019; Krüger, 2015). Around $80 \%$ of each dollar lost in the share value of a company, following judiciary prosecution, comes from market-imposed penalties, leaving only $20 \%$ of losses to fines and disbursements imposed by authorities $^{19}$ (Karpoff et al., 2008). A foreign company with a physical presence in the US typically has branches, offices, jobs, and businesses (Kerner, 2014) that make it likely reputational penalties will be harsher, as they potentially involve a relatively larger share of its economic activities.

By offering cooperation, companies can minimize these penalties, and signal compliance with ESG principles. They are able to frame the misconduct as the behavior of a "bad apple" inside the company, rather than a structural issue (Garrett, 2014). Having more at stake, companies with a physical presence in the US have larger incentives to cooperate with authorities, in order to minimize such penalties and signal compliance with ESG principles. In other words, the reputational opportunity cost of refusing cooperation is much stronger for them. This provides prosecutors the information they need to bring a case and makes it more likely that they will be able to enforce regulation.

\footnotetext{
${ }^{18}$ In the years when cases of foreign bribery peaked, for instance, the DOJ prosecuted less than 15 yearly cases in all.

${ }^{19}$ This means that it is not relevant whether a firm was actually guilty of the alleged crime or not: firms suffer harsh reputational penalties even as a result of mere criminal allegations.
} 
Thus, I expect foreign companies with extensive economic activities in the country will be more likely to be prosecuted than those with no such presence. In the running example introduced above, Red Apple will be more likely to cooperate with prosecutors than Morley. This makes the Red Apple case one where the availability of information will likely be higher than in the Morley one. All else equal, I expect US authorities will be more likely to dedicate scarce legal resources to cases against foreign companies with investment in the country, than others.

\section{The US and the global anti-bribery regime}

A study aimed at explaining the selection of foreign companies by US prosecutors runs into a very obvious problem: only enforced cases are observable. Cases agencies had information on and decided not to prosecute are, instead, impossible to observe. My solution to this problem exploits two unique features of the case I study: the US-sponsored international anti-bribery regime that emerged in the 1990s. First, construction of the regime diffused US-like anti-bribery policies to its member states. Second, it enabled US authorities to enforce their own anti-bribery policy extraterritorially.

The United States was the first country to adopt a regulation preventing American companies from paying bribes to foreign public officials, with the 1977 Foreign Corrupt Practices Act (FCPA ${ }^{20}$. Ever since the law was adopted, US administrations have faced concerns by American companies who were worried the law would disadvantage them vis-à-vis foreign competitors that did not risk judiciary repercussions for paying bribes overseas ${ }^{21}$. They responded to such concerns in two ways. First, they lobbied for the adoption of a common anti-bribery regulation among partner countries, an effort which resulted in a number of anti-bribery international agreements. Second, they expanded the jurisdiction of the FCPA to cover non-US companies with rounds of amendments in 1988 and in 1998.

Two consequences of its peculiar history make the regime an optimal case to study why US authorities choose to prosecute certain non-US companies. First, countries participating in this US-sponsored international anti-bribery regime have adopted policies that closely resemble the US FCPA, and that prohibit the same type of corrupt payments (Brewster, 2014). This is particularly true for the 43 countries taking part, alongside the US, to the OECD Anti-Bribery Convention. The Convention is an instrument of hard international law mandating its participants to enforce anti-bribery standards against foreign corrupt payments by their MNCs. The existence of this agreement makes it possible to observe, from 1997 on, a much larger set of violations of anti-bribery rules by companies around the world, than what would be observed by simply looking at US-based enforcement.

\footnotetext{
${ }^{20}$ The FCPA emerged from the blows of the Watergate scandal. Among the many illicit payments uncovered by the Watergate Special Prosecutor offices, US corporations were found to have paid bribes in various foreign countries to members of governments, of cabinets, of parties, and of the public administration believed to be close to American interests and values (Abbott and Snidal, 2002).

${ }^{21} \mathrm{~A}$ few countries, notably France and West Germany, had even made cross-border bribery payments tax-deductible for their companies (Gutterman, 2015).
} 
Second, the construction of the regime dramatically expanded US authority over non-US companies. After its 1998 amendments the FCPA formally applies to foreign corporations suspected of foreign bribe payments with even a marginal connection to the US. This includes non-US companies listed on a US stock exchange or otherwise obliged to submit periodic reports to the SEC, but also non-issuing companies furthering any act of bribery to a foreign official while in the US (Leibold, 2014). The latter category does not cover exclusively misbehavior physically occurring on US soil. In fact, the use of US mail, phone calls or internet communication using US providers, interstate or international travel with connection to the US, and even bank wire transfers or transactions operated in US dollars can be sufficient for the SEC and the DOJ to invoke jurisdiction on a company from anywhere in the world, as long as such connections were instrumental to the corrupt exchange. This interpretation of the "presence doctrine" (see footnote 3) is so broad that often its justification appears dubious to legal experts (Garrett, 2011). Cross-border networks of mutual legal assistance among authorities belonging to this regime facilitates US federal agencies to enforce their laws against foreign subjects (Kaczmarek and Newman, 2011). As a result, nowadays virtually all corporations under the regulatory umbrella of the anti-bribery regime are considered liable under FCPA provisions, regardless of their presence on US soil (Leibold, 2014).

By focusing on this specific regime I am thus able to observe a vast set of similar violations of anti-bribery standards by non-US companies. Some were investigated by US authorities, others were not. Given that the US has the authority to behave as the "global sheriff" of this regime and prosecute virtually all these cases, I am then able to distinguish between cases involving non-US companies that were prosecuted by US authorities and those that were only prosecuted by non-US courts.

I argue these cases comprise the ones information was available for. This observable set clearly does not include all possible violations of anti-bribery standards. Namely it does not include cases that $(i)$ no involved authority had information on and that (ii) all informed authorities willingly chose not to investigate. The first source of selection does not really represent an issue for this study, as US authorities cannot choose to focus on violations nobody knew of. The second, instead, might introduce an issue of selection bias. If unobserved cases willingly overlooked by all informed judicial authorities were also systematically different in their US investment behavior, I would be unable to observe certain bribery cases that differ systematically from the observable ones in terms of the involved companies' presence in the US. I assume this is not happening: hence deliberate selection of non-US cases out of the set of observable ones is independent of the US ownership structure of the involved companies ${ }^{22}$. Even in the restrictive case this assumption were violated, yet, focusing on observable cases allows to explain what drives US prosecution of non-US companies in publicly known violation of the anti-bribery regime. Next section details how I construct an original dataset recording anti-bribery violations by non-US companies.

\footnotetext{
${ }^{22} \mathrm{~A}$ violation of this assumption would occur, for instance, if overseas bribe payments by non-US companies with a significantly large presence in the US were known by authorities of some countries and were willingly and coordinately overlooked. I believe this scenario to be rather unrealistic, particularly since countries where bribes were paid can often extract a valuable reimbursement from judicial actions.
} 


\section{Data collection}

My argument explains decisions of US authorities to investigate a non-US company as a function of its investment in the US. I test this expectation in the case of the anti-bribery regime. Two crucial pieces of information are therefore required. First, I need to retrieve information on cases of corporate bribery by non-US companies which were enforced and were not enforced by US authorities. Second, I need to reconstruct investment of the involved firms in the US (or lack thereof). The next two subsections detail how I collected data from different sources and constructed an original dataset containing both pieces of information.

\subsection{Anti-corporate bribery enforcement cases}

I retrieve information on anti-bribery enforcement actions by US and non-US authorities combining different data sources. The main one is the TRACE Compendium. TRACE International is a business association providing risk management services, particularly focused on anti-bribery legal, reputational, and economic risk. Its Compendium ${ }^{23}$ is an open and easily accessible database made of 841 text documents summarising events of cross-border corporate corruption in violation of the international anti-bribery regime, and related law enforcement actions. TRACE constructs it drawing from legal documents, newspaper articles, and leakages or official releases of corporate files.

Two features make this database the perfect source for my data collection. First, the case selection. TRACE only considers events of cross-border corruption where the bribe-payer is an (individual acting on behalf of an) enterprise headquartered in a certain country and the bribe-payee is a public official of a different nationality. It does not consider events of corruption that are purely domestic, i.e. those where bribe-payer and payee are of the same nationality. These events technically do not fall under the scope of the international anti-bribery regime. Second, TRACE reports events of anti-bribery law enforcement initiated by US and non-US authorities alike. This allows me to tell cases that were enforced by US prosecutors from those that US agencies did not enforce.

I employ a mix of web-scraping techniques and hand-coding to collect information from these 841 text documents ${ }^{24}$. A single TRACE document can be particularly complex. It can refer to a single bribepayer company or multiple ones. Under the same corrupt scheme, bribe-payers can funnel illicit money into the pockets of public officials from a single country or multiple ones. Finally, enforcement actions by a national authority can cover any or all of these criminal transactions. I carefully disentangle this complex information and code documents appropriately, obtaining information on individual payments

\footnotetext{
${ }^{23}$ See: https://www.traceinternational.org/resources-compendium

${ }^{24} \mathrm{I}$ check completeness of this dataset drawing from data generously provided by Escresa and Picci (2017). I also check my data using sources specific to US FCPA enforcement: Garrett and Ashley (2019)'s data on DOJ prosecution, Stanford Law School's Foreign Corrupt Practices Act Clearinghouse dataset (see: http://fcpa.stanford.edu/ enforcement-actions.html?page=1.0), and data from the Violation Tracker by Good Job First (see: https://www. goodjobsfirst.org/violation-tracker). I test accuracy of coded information by randomly selecting $30 \%$ of the observations and checking the way automated techniques coded information.
} 
made by specific subjects to foreign officials of a certain nationality, and enforced by a given national authority.

Once I have obtained information on events of anti-bribery enforcement, I collect data on the corporate identity of the bribe-payers. First, I identify the company paying the bribe from the scraped TRACE documents. Where individuals are reported to have paid a bribe, I try to gather information on the company they were bribing on behalf of, if the information is available. Where this information is not available, I flag these records as payment made by individuals, and I later discard them ${ }^{25}$. I draw on several providers of company data to retrieve correct information on the headquarter country and identity of each corporate bribe-payer. My main source for this is Bureau van Dijk's Orbis Corporate Ownership database. Where Orbis does not report information on the included companies in my dataset, I draw from alternative sources ${ }^{26}$. I retrieve this information employing mandatory filings by civil authorities in charge of overseeing security markets (like the SEC or U.K. Companies House reports), datasets about leaked offshore corporate documents ${ }^{27}$, NGO information (like those provided by the UN Global Compact program, or development agencies), and private information providers on company data (Bloomberg, Dun \& Bradstreet, and Crunchbase).

The final dataset I obtain is composed of 3,038 distinct events. The unit of such dataset is a bribe payment by a single subject (a company or an individual) to public officials of a single nationality, prosecuted by authorities of a single country. Reported bribes were paid by a total of 774 companies headquartered in 76 different countries, and by 34 individuals of 16 different nationalities. They involve a total of 1,245 different events of cross-border bribe payments to foreign officials from 160 different countries, from 1972 to 2021. A total of 1,583 distinct enforcement events ${ }^{28}$ were initiated by national agencies of 111 countries in total.

This rich dataset contains some information that is not necessary for my study. I therefore proceed at selecting only the relevant information. First I remove all observations referring to events of corruption taking place before 1997. I consider this year the real birth of the anti-bribery regime, with the ratification of the OECD Anti-Bribery Convention. Legal research has shown that the agreement represented a turning point for the possibility to enforce the US FCPA (Brewster, 2014). Next, I remove all cases of cross-border bribery where information on the company individuals were bribing on behalf of was not available. For the sake of my argument I do not consider these cases as events of illicit corporate payments, but as individual criminal actions.

\footnotetext{
${ }^{25}$ In 45 TRACE records it was not possible to discern which companies individual bribe-payers were paying on behalf of. In the majority of these cases criminals set up fictitious firms or shell companies to conceal bribe-payments and/or pocket kickbacks. Usually they conceived complex schemes for securing private advantages.

${ }^{26}$ Only 45 out of 774 companies were not appearing in Orbis and required to obtain information with alternative means.

${ }^{27}$ Like https://off shoreleaks.icij.org or https://wikileaks.org.

${ }^{28}$ This figure departs significantly from official TRACE statistics because I count enforcement actions differently. TRACE considers multiple events of enforcement by agencies from different countries as a single event, while in my dataset each individual enforcement by an agency represents a single event of prosecution, even if multiple countries are prosecuting the same corruption case.
} 
My interest is in explaining extraterritorial prosecution of non-US companies by American federal authorities. I therefore discard all cases of cross-border bribery where the bribe-payer company is a US-incorporated firm. Cases in this category do not fall under the extraterritorial application of FCPA terms, therefore they are not of interest for the study. Finally, I discard cases where the bribe-payee is a US public official. Cases under this category do not fall under the jurisdiction of the FCPA, and are generally prosecuted in light of legislations against domestic bribery.

These selections leave me with a dataset of 1,921 observations involving 428 non-US companies. These firms were involved in a total of 674 distinct corrupt exchanges involving non-US public officials, prosecuted in 932 different events of enforcement around the world. Finally, I collapse these observations by firm and obtain my binary dependent variable Investigation measuring whether each firm of the 428 non-US companies involved in at least one bribery event was ever investigated by US authorities or not.

\subsection{US investment}

I collect information on the presence of these companies in the US economy. I aim at constructing a binary firm-level explanatory variable $U S$ Subsidiary that takes value 1 if and only if a given company has a subsidiary in the US.

I rely on Orbis to obtain data on investment of the companies of interest through US subsidiaries. Out of the 428 companies in the dataset, 402 have information available in Orbis. I collect data on subsidiaries of each of these 402 firms around the world. Orbis reports information gathered from mandatory filings made by companies to agencies regulating securities (like the SEC in the US or Companies House in the $\mathrm{UK})$.

Orbis reports that the 402 companies of interest own a total of 58,734 unique subsidiaries in 198 different countries. For most of them, information is provided on their geolocation, their economic size (total assets and turnover), and number of employees. Not all these ownership relations are of interest, though. Some of these subsidiaries can be shell companies, financial services, and short-term ownership operations that have little to do with the type of long-term foreign investment implied by my argument (Kerner, 2014). I proceed at making appropriate selections following practices recommended by previous studies that use Orbis data (Beazer and Blake, 2018) and established guidelines on dealing with this data source (Kalemli-Ozcan et al., 2015).

For each of the 402 companies in the sample, I get information on whether it owns at least one US subsidiary. I define a subsidiary according to two criteria. First, it should not be what Orbis classifies as a "small" company. Hence, I consider only subsidiaries that haver higher operating revenue than one million US dollars, more than two million US dollars in total assets, and more than 15 employees. Second, a parent should enjoy at least $50 \%$ of voting power in a company for it to be considered its subsidiary (Kalemli-Ozcan et al., 2015). These two criteria ensure I am only considering non-US long-term and 
substantive investment in the US, the kind of enterprise that is likely to induce reputational liabilities advanced by my theory.

For each company in the dataset I construct my explanatory variable of interest US Subsidiary measuring whether the company has at least one subsidiary in the US. Out of the 402 companies, 49 have a subsidiary in the country ${ }^{29}$ while 353 do not.

\subsection{Firm-level covariates}

My argument expects non-US companies suspected of bribery will be disproportionately likely to be investigated by federal authorities if they have an investment in the US. The effect of interest can be confounded by a number of potential factors that the analysis should control for. I rely on Orbis to obtain information on all of these firm-level covariates.

First, companies with more investment around the world can be more likely to invest in the US and also to be involved in events of bribery. I therefore obtain information on the number of total subsidiaries (defined following the same criteria outlined above) for each company - Global Subsidiaries - and for the number of branches directly controlled by each company - Global Branches. The number of employees can also play a similar confounding effect: companies with more employees around the world can have better resources to invest in the US and be more likely to be exposed to bribery. I therefore measure the logarithm of the total number of employees for each company $+1-$ Global Employees $(\log +1)$.

Characteristics of the parent company can also confound the relationship of interest. Richer firms might have the means and interest to embark in a US investment, an initiative which entails considerable sunk costs for a parent company. At the same time, they might also be more easily target of bribe requests when conducting their business, hence they might risk appearing on US authorities' radar more often. I therefore measure the average Parent Revenues and Parent Assets as reported by Orbis, measuring respectively operating revenues and total assets' worth in millions of US dollars. I also measure the average Parent Employees to get a sense of the firm's size.

Finally, US authorities might investigate more thoroughly companies from specific home countries because of characteristics that are completely unrelated to their investment in the US. These reasons can confound the relationship of interest if they also correlate with the likelihood that companies of these nationalities are involved in events of bribery. Industry-specific features can also play a similar role. To account for both problems, I record the home country of each company and its industrial sector based on the two-digits North American Industry Classification System (NAICS). I introduce fixed effects at these levels to remove such heterogeneity.

\footnotetext{
${ }^{29}$ Imposing the condition that only non-small companies count as subsidiaries shrinks substantively this "treatment group". Relaxing it increases the treatment group to a total of 174 companies. Results presented in the next section are overall the same (although slightly smaller in size) when this condition is relaxed.
} 


\subsection{Data description}

I present summary statistics of my cross-sectional dataset in appendix (Table A.1). Table 1 provides information on the average value of each variable separating between the two groups of companies with or without a US subsidiary. Non-US companies with no US subsidiaries have a baseline 0.34 probability of being investigated by US authorities when they are involved in events of bribery. This confirms the vigorous extraterritorial activity of federal authorities documented by previous studies. This probability increases by almost 0.40 in the group of companies with at least one US subsidiaries. Firms in this group have a 0.73 probability of being investigated by US authorities, when they are involved in events of bribery. The difference is statistically distinguishable from zero at conventional levels of significance.

Table 1: Bribe-payer non-US companies. Observable covariates balance table

\begin{tabular}{lcccccccc}
\hline & \multicolumn{2}{c}{ No Subsid. $(\mathrm{N}=353)$} & & \multicolumn{2}{c}{ Subsid. $(\mathrm{N}=49)$} & & \\
\cline { 2 - 3 } & Mean & Std. Dev. & & Mean & Std. Dev. & Diff. in Means & Std. Error \\
\hline Investigation & 0.34 & 0.48 & & 0.73 & 0.45 & 0.39 & 0.07 \\
Investigation (share) & 0.31 & 0.45 & & 0.62 & 0.43 & 0.30 & 0.07 \\
Global Subsidiaries & 0.01 & 0.02 & & 0.04 & 0.04 & 0.03 & 0.01 \\
Global Branches & 0.02 & 0.12 & & 0.07 & 0.32 & 0.05 & 0.05 \\
Global Employees (log+1) & 0.85 & 1.37 & & 3.43 & 1.12 & 2.58 & 0.18 \\
Parent Revenues (mean) & 0.12 & 0.37 & & 0.39 & 0.46 & 0.27 & 0.07 \\
Parent Assets (mean) & 0.37 & 1.49 & & 2.79 & 6.17 & & 2.42 & 0.89 \\
Parent Employees (mean) & 0.00 & 0.00 & 0.00 & 0.00 & & 0.00 & 0.00 \\
\hline
\end{tabular}

This difference provides some initial and descriptive evidence of the relationship advanced by my argument. Yet, Table 1 also shows that almost all the other covariates are strongly unbalanced in the sample. On average, firms with at least one investment in the US tend to have more extended activities in the world, and they tend to be larger. To the extent that these features correlate with the group composition too, the difference-in-means presented above provides a confounded picture. Next section adopts a selection on observables design to hold constant these observable potential sources of endogeneity.

\section{Selection on observables design}

In this section I estimate a series of linear probability models (LPM) of the Investigation binary dependent variable. I explain the dependent variable using my main explanatory variable US Subsidiary and I hold constant relevant observable sources of endogeneity presented in the previous section. I estimate LPMs using ordinary least squares (OLS) for ease of interpretation of their coefficients. I cluster all standard errors at the home-country level to account for possible correlation at this level in the error term and obtain larger measures of uncertainty that factor in co-dependence of observations.

Table 2 reports LPM estimates. I include my control variables step-wise and carefully given the 
Table 2: Linear probability models of Investigation. Binary main explanatory variable

\begin{tabular}{|c|c|c|c|c|c|}
\hline & (1) & $(2)$ & $(3)$ & (4) & $(5)$ \\
\hline US Subsidiary & $\begin{array}{c}0.392^{* * *} \\
(0.076)\end{array}$ & $\begin{array}{c}0.328^{* * *} \\
(0.087)\end{array}$ & $\begin{array}{c}0.302^{* *} \\
(0.094)\end{array}$ & $\begin{array}{c}0.259^{*} \\
(0.105)\end{array}$ & $\begin{array}{c}0.271^{* *} \\
(0.100)\end{array}$ \\
\hline Global Subsidiaries & & $\begin{array}{l}-0.992 \\
(0.823)\end{array}$ & $\begin{array}{c}-0.736 \\
(1.033)\end{array}$ & $\begin{array}{c}0.536 \\
(1.174)\end{array}$ & $\begin{array}{c}0.468 \\
(1.058)\end{array}$ \\
\hline Global Branches & & $\begin{array}{c}0.356^{* *} \\
(0.125)\end{array}$ & $\begin{array}{c}0.277^{*} \\
(0.134)\end{array}$ & $\begin{array}{c}0.225^{* *} \\
(0.071)\end{array}$ & $\begin{array}{c}0.172 \\
(0.112)\end{array}$ \\
\hline Global Employees $(\log +1)$ & & $\begin{array}{c}0.030 \\
(0.022)\end{array}$ & $\begin{array}{c}0.024 \\
(0.028)\end{array}$ & $\begin{array}{c}0.015 \\
(0.026)\end{array}$ & $\begin{array}{c}0.037 \\
(0.031)\end{array}$ \\
\hline Parent Revenues (mean) & & & $\begin{array}{l}0.158^{*} \\
(0.079)\end{array}$ & $\begin{array}{l}0.183+ \\
(0.099)\end{array}$ & $\begin{array}{c}0.103 \\
(0.146)\end{array}$ \\
\hline Parent Assets (mean) & & & $\begin{array}{c}0.010 \\
(0.007)\end{array}$ & $\begin{array}{c}0.017^{* *} \\
(0.006)\end{array}$ & $\begin{array}{l}0.016^{*} \\
(0.008)\end{array}$ \\
\hline Parent Employees (mean) & & & $\begin{array}{c}-73.990^{* * *} \\
(17.972)\end{array}$ & $\begin{array}{c}-80.766^{*} \\
(34.102)\end{array}$ & $\begin{array}{l}-80.449 \\
(71.604)\end{array}$ \\
\hline (Intercept) & $\begin{array}{c}0.343^{* * *} \\
(0.041)\end{array}$ & $\begin{array}{c}0.319^{* * *} \\
(0.048)\end{array}$ & $\begin{array}{c}0.338^{* * *} \\
(0.059)\end{array}$ & $\begin{array}{l}-0.028 \\
(0.066)\end{array}$ & $\begin{array}{c}-0.347+ \\
(0.177)\end{array}$ \\
\hline Country FE & & & & Yes & Yes \\
\hline Industry FE & & & & & Yes \\
\hline Num.Obs. & 402 & 402 & 303 & 303 & 301 \\
\hline $\mathrm{R} 2$ & 0.069 & 0.087 & 0.110 & 0.388 & 0.452 \\
\hline R2 Adj. & 0.067 & 0.078 & 0.088 & 0.243 & 0.266 \\
\hline $\mathrm{F}$ & 29.678 & 9.483 & 5.188 & 2.667 & 2.430 \\
\hline
\end{tabular}

$+\mathrm{p}<0.1,{ }^{*} \mathrm{p}<0.05,{ }^{* *} \mathrm{p}<0.01, * * * \mathrm{p}<0.001$

Note: Coefficients estimated using OLS. Standard errors are clustered at the home country level.

limited number of observations in my dataset and data missingness for some covariates. This also avoids problems of suppression effects in a selection on observables design (Lenz and Sahn, 2020). The first model introduces only my binary explanatory variable US Subsidiary. Its estimated effect is obviously the exact same difference-in-means reported in Table 1: non-US companies with at least one subsidiary in the US are about 0.39 more likely to be investigated by federal authorities when they are involved in events of bribery, over a baseline likelihood of 0.34. In the second model I introduce controls relative to the global spread of a company. I control for the worldwide number of subsidiaries, of branches, and for the (logged) number of employees. The estimated effect of US Subsidiary remains substantively the same: an increase of about 0.33 in the likelihood of being investigated by federal authorities.

In model 3, I introduce controls relative to the size of the company (average revenues, assets, and number of employees). Introducing these controls shrinks the sample size considerably due to missing data for these variables. Nevertheless the effect of US Subsidiary remains substantively the same: an increase by about 0.30 in the probability of being investigated. Finally, in models 4 and 5 I control for country-specific and industry-specific idiosyncratic heterogeneity by including a categorical home country variable (Country FE) and a categorical industry variable (Industry FE). Estimates still show that companies with at least one US Subsidiary are about 0.26 to 0.27 more likely to be investigated by federal authorities. 
All estimated effects of US Subsidiary are distinguishable from zero at a 0.05 conventional level of significance. The effect size in the most conservative of the estimated models (model 4, with the smallest point estimate and the largest measure of uncertainty) is such that the probability of being investigated by federal authorities increases by a factor between 0.05 and 0.47 for firms with at least one US Subsidiary (when looking at the boundaries of a $95 \%$ confidence interval).

I then test robustness of these results. All tests are reported and discussed in appendix. I first restrict the causal quantity of interest to an average treatment effect on the treated (ATT) companies. I estimate it in two ways: with an OLS regression imputation estimator from Lin (2013) and with a Mahalanobis matching procedure. Results are consistent with the ones presented here. Next, I show that estimates are not model-dependent. I employ a logit model, a random effect linear model, and a random effect logit model. Results hold. I also show results are robust to alternative operationalizations of my dependent and main explanatory variable, when adopting all previous model choices.

\subsection{Discussion}

Estimates provided in the selection on observables analysis inform us that, on average, non-US companies that are exposed to the US economy through an investment in the country are at least 0.26 more likely to be investigated by US authorities than comparable companies with no investment in the US. Internal validity of these results rests on the demanding conditional independence assumption, which claims that models include all potential factors causing the dependent variable while simultaneously correlating with the main explanatory variable. This assumption is essentially untestable and hard to defend. It is, yet, possible to hypothesize the direction of potential sources of bias to understand the extent to which the sign of provided estimates is credible.

One potential source of omitted variable bias is the unobservable preference of companies for bribing in international business. Non-US companies that are more inclined to secure contracts by means of bribing are more likely to end up being targeted by US authorities, simply because they have higher chances to appear on their radar. At the same time, they are likely aware of the extraterritorial provisions of the American anti-bribery policy. They might therefore decide to reduce their exposure to the US economy, by avoiding investing in the country, precisely in order to limit the risk of prosecution. If that is the case, then the propensity to bribe is a potential confounder threatening results presented.

Another likely confounder is the propensity to pay larger bribes. Non-US companies that are more used to pay larger bribes in international business might be more likely target of US authorities (Choi and Davis, 2014). At the same time, they might have an incentive to limit their presence in the US economy to avoid the risk of prosecution.

If so, yet, the direction of the resulting selection bias would be negative, because propensity to bribe (or propensity to pay larger bribes) would be positively causing the dependent variable but negatively 
affecting exposure to the US economy. Therefore estimates presented in Table 2 would in fact be underestimating the real effect size of US Subsidiary on Investigation. Their point estimates would be smaller than the real effect size. This is true also for other sources of negative selection bias. They would threaten the substantive validity of estimated effects because they result in coefficients that are smaller than the real effect sizes. Yet, even if point estimates would be unreliable, the effect of exposure to the US economy on the probability of being investigated by US authorities would remain positive.

Potential sources of selection bias should be positive in order to effectively threaten the sign of the estimates provided. Their effects on the dependent variable and treatment variable US Subsidiary should have the same sign (either both positive or both negative). My selection on observables design assumes similar sources of endogeneity are not taking place. Is this reasonable? How large should a hypothetical unobserved confounder be in order to threaten the presented estimates? Recent tools for sensitivity analysis introduced by Cinelli and Hazlett (2020) allow to ground this assumption into more concrete terms. These tools allow the analyst to use an observed severe confounder as a reference point to study how larger an unobserved confounder should be in order to flip sign of estimated effect or to make it statistically insignificant. Impact of confounders is expressed in terms of partial R-squared, i.e. in terms of the proportion of variation of the treatment or outcome variable that the confounder explains.

I select the size of the parent firm (expressed in terms of asset value) as the most severe observed confounder in my dataset. Larger parent companies have the means to invest in the US market and they also tend to be more likely targets of US prosecutors' activity. There are substantial barriers and costs to invest into the US market. An investment typically consists in the establishment (or acquisition) of expensive productive sites in the host country (Kerner, 2014). This represent a significant sunk cost (Jensen et al., 2012). Investing in the US also comes with costs of a different nature. Investors should adapt to the US regulation. They are required to file detailed periodical reports to the SEC. Files must abide by a specific form and typically require the assistance of legal consultants. Legal and organizational costs also come from adapting to the US regulatory framework. This is a documented problem specifically in the case of anti-bribery regulations. Whereas US companies have been subject to FCPA terms since 1977, a non-US company incurs in significant organizational costs to re-organize its structure in order to be FCPA-compliant (Garrett, 2014). On average, only larger firms might be able to absorb similar costs.

Larger companies, in turn, might also appear more often on US authorities' radar. They are more likely to have extended operations around the globe, for the same reason as they are more likely to invest in the US. Hence, the likelihood that they end up being involved in bribery scandals is higher than for smaller firms. US authorities will therefore be more likely to investigate these companies, all else equal. The size of a company is hence likely to be a relevant confounder of my effect of interest. If this argument is correct, this confounder introduces a positive selection bias, the kind of bias my analysis should be concerned about. I then proceed to test sensitivity of the estimated effect from model 5 in Table 2 using 
this observed covariate as a benchmark ${ }^{30}$.

Table 3 provides a summary of its sensitivity to omitted variable bias. In this model the treatment variable alone explains about $3.6 \%$ in the variation of the outcome variable. This portion is rather large, considering that it stands even after accounting for the explanatory power of covariates and fixed effects. The sensitivity analysis informs that it would take an unobserved confounder explaining more than $17.5 \%$ of the remaining variance of both treatment and outcome variables to bring the point estimate to 0. Such a large effect on both variables appears unreasonable, thus providing confidence in the estimated effect. Yet, the table also informs that an unobserved confounder explaining $5.9 \%$ of the residual variation of treatment and outcome variables would be sufficient to move the t-statistic of the estimated effect within the $95 \%$ critical values interval, thus making it no longer statistically significant.

Table 3: Sensitivity analysis of estimated effects

\begin{tabular}{lrrrrrr}
\multicolumn{7}{c}{ Outcome: Investigation } \\
\hline \hline Treatment: & Est. & S.E. & t-value & $R_{Y \sim D \mid \mathbf{X}}^{2}$ & $R V_{q=1}$ & $R V_{q=1, \alpha=0.05}$ \\
\hline$U S$ Subsidiary & 0.271 & 0.094 & 2.88 & $3.6 \%$ & $17.5 \%$ & $5.9 \%$ \\
\hline $\mathrm{df}=224$ & \multicolumn{7}{c}{ Bound (1x Parent } & Assets): & $R_{Y \sim Z \mid \mathbf{X}, D}^{2}=0.8 \%$, & $R_{D \sim Z \mid \mathbf{x}}^{2}=6.6 \%$
\end{tabular}

Figure 2 provides additional information by comparing the size of a hypothetical unobserved confounders to that of the Parent Assets covariate. Figure 2a shows that it would take an unobserved confounder more than five times as large as Parent Assets to flip the sign of the point estimate. If there existed an omitted variable even five times as large as the chosen benchmark, the estimated effect would still be positive and sizeable (a 0.066 increase in the probability of Investigation). Again, it seems unreasonable to have such a large unobserved confounder in place, which provides confidence on the estimated effects. Yet, Figure $2 \mathrm{~b}$ provides a cautionary tale. An unobserved confounder that is just twice as large as Parent Assets would move the t-statistics to a value of 1.995 , just outside of the conventional critical values of a 95\% confidence interval. Any larger unobserved confounder would move this quantity to a range where the estimated effect is no longer statistically significant at a conventional 0.05 level.

My estimated effect therefore rests on the assumption that hypothetical unobserved confounders of this size do not exist. Table 3 and Figure 2 provide concrete boundaries to the impact an omitted variable should have on treatment and outcome variables in order to make the effect estimated in this section completely unreliable.

\section{Conclusion}

Sovereign states adopt extraterritorial provisions to impose their domestic regulations on foreign subjects. These provisions are often part of international regulatory regimes countries established to further environmental, social, and governance (ESG) values along global supply chains and prohibit nefarious

\footnotetext{
${ }^{30}$ I choose model 5 as it is the most complete specification in my main analysis.
} 


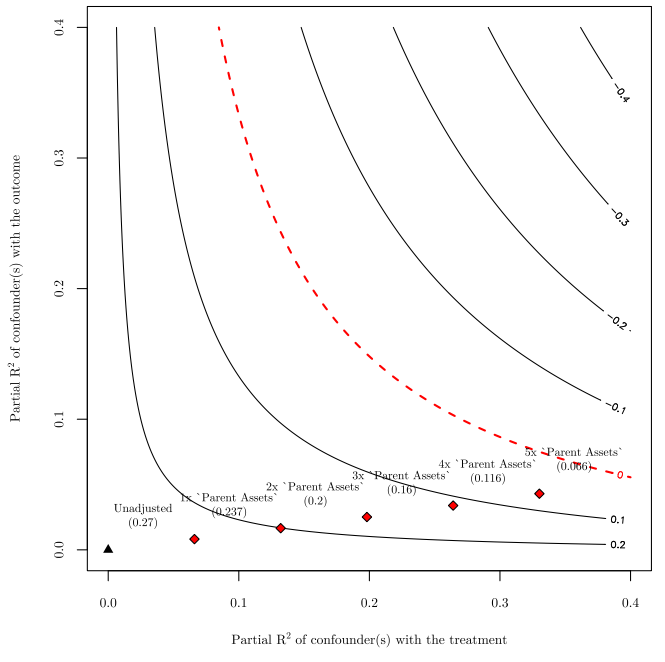

(a) Point estimates

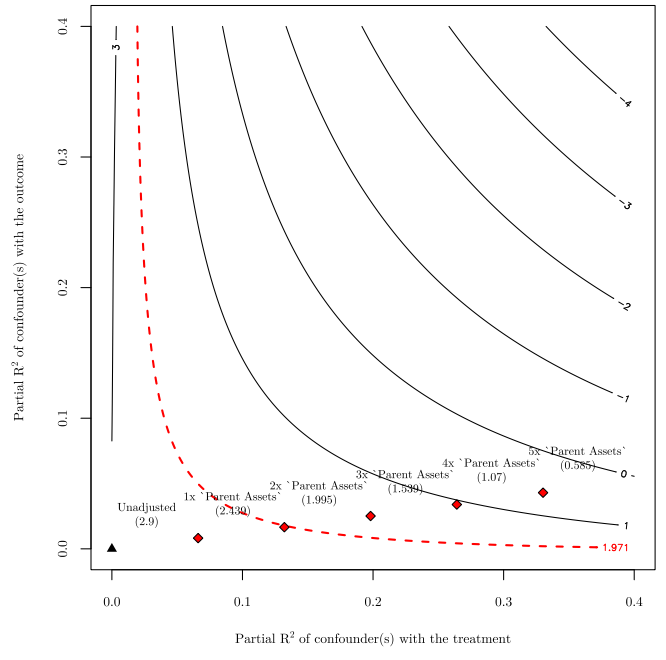

(b) T-statistics

transactions. States that apply these policies vigorously effectively behave as "global sheriffs" of these regimes. The US regularly prosecutes foreign companies in violation of domestic economic policies and levies fines in the order of billions of dollars. Nonetheless, US authorities only prosecute a fraction of potential cases the country has jurisdiction on. Determinants of such selection of foreign companies are still understudied in the international political economy scholarship.

In this paper I studied investigation of specific foreign companies suspected of illicit transactions by US authorities. I argued that US federal agencies are more likely to investigate a foreign company if that firm is exposed to the US economy through a foreign investment in physical assets in the country. A similar type of exposure increases the reputational damage that the company suffers for allegations of crime committed abroad. Authorities have bureaucratic and professional incentives to leverage such reputational liabilities and more easily win a case. Potential losses induced by staying under the spotlight of the local public opinion induce the company to settle charges out-of-court. The company is thus incentivized to cooperate with prosecutors and share information they need to win a case. Overall, an investment in the US makes these companies an easier target for federal agencies in comparison to similar foreign companies with no physical presence in the country.

I test my argument focusing on the case of the anti-bribery regime. I collect a novel dataset on accusations of bribery against multinational companies by web-scraping documents from an archive of bribery events. I link this data with information on the subsidiary structure of non-US companies alleged to have paid bribes in international business transactions. Linear models estimate that the probability that US agencies will investigate a non-US company suspect of bribery increases by at least 0.26 when the firm has one subsidiary in the US.

Results show that extraterritoriality can be a powerful tool to counter forms of regulatory arbitrage 
by companies exploiting multinational ownership to evade regulation. Yet, this regulatory strategy still needs some kind of territorial leverage. Even a powerful regulator like the US is less likely to investigate a foreign company in the absence of such territorial bargaining chip. Findings potentially travel to other regulatory powers that stretch the arm of their laws beyond their borders, like the United Kingdom or Switzerland, and have especially relevant implications for weaker ones, like Nigeria (Crasnic et al., 2017). My study also provides a new perspective on the so-called "weaponized interdependence" argument, which claims that states can leverage their economic power to exercise their regulatory prerogatives. I show that this dynamic is not necessarily conducted in pursuit of national interest, and can be the outcome of purely domestic and bureaucratic mechanisms. 


\section{References}

Abbott, K. W. and Snidal, D. (2002). Values and interests: International legalization in the fight against corruption. The Journal of Legal Studies, 31(S1):S141-S177.

Alexander, C. R. and Arlen, J. (2018). Does conviction matter? the reputational and collateral effects of corporate crime. In Research handbook on corporate crime and financial misdealing. Edward Elgar Publishing.

Arel-Bundock, V. (2017). The unintended consequences of bilateralism: Treaty shopping and international tax policy. International Organization, 71(2):349-371.

Aronow, P. M. and Samii, C. (2016). Does regression produce representative estimates of causal effects? American Journal of Political Science, 60(1):250-267.

Baer, M. H. (2018). When the corporation investigates itself. In Research Handbook on Corporate Crime and Financial Misdealing. Edward Elgar Publishing.

Baradaran, S., Findley, M., Nielson, D., and Sharman, J. (2012). Does international law matter. Minn. L. Rev., 97:743.

Beazer, Q. H. and Blake, D. J. (2018). The conditional nature of political risk: How home institutions influence the location of foreign direct investment. American Journal of Political Science, 62(2):470485.

Bell, A. and Jones, K. (2015). Explaining fixed effects: Random effects modeling of time-series crosssectional and panel data. Political Science Research and Methods, 3(1):133-153.

Brewster, R. (2014). The domestic and international enforcement of the OECD Anti-Bribery Convention. Chi. J. Int'l L., 15:84.

Bukovansky, M. (2006). The hollowness of anti-corruption discourse. Review of International Political Economy, 13(2):181-209.

Capelle-Blancard, G. and Petit, A. (2019). Every little helps? ESG news and stock market reaction. Journal of Business Ethics, 157(2):543-565.

Chapman, T. L., Jensen, N. M., Malesky, E. J., and Wolford, S. (2020). Leakage in international regulatory regimes: Did the OECD Anti-Bribery Convention increase bribery? Quarterly Journal of Political Science.

Choi, S. J. and Davis, K. E. (2014). Foreign affairs and enforcement of the Foreign Corrupt Practices Act. Journal of Empirical Legal Studies, 11(3):409-445. 
Choi, S. J. and Pritchard, A. (2018). Securities law and its enforcers. In Research Handbook on Corporate Crime and Financial Misdealing. Edward Elgar Publishing.

Cinelli, C. and Hazlett, C. (2020). Making sense of sensitivity: Extending omitted variable bias. Journal of the Royal Statistical Society: Series B (Statistical Methodology), 82(1):39-67.

Cooley, A. and Sharman, J. (2017). Transnational corruption and the globalized individual. Perspectives on Politics, 15(3):732-753.

Crasnic, L., Kalyanpur, N., and Newman, A. (2017). Networked liabilities: Transnational authority in a world of transnational business. European Journal of International Relations, 23(4):906-929.

Crippa, L. (2021). The conditional arm of the law. the effect of the OECD Anti-Bribery Convention on foreign direct investment. Working paper.

Davis, K. E. (2019). Between Impunity and Imperialism: The Regulation of Transnational Bribery. Oxford University Press.

DeHaan, E., Kedia, S., Koh, K., and Rajgopal, S. (2015). The revolving door and the SEC's enforcement outcomes: Initial evidence from civil litigation. Journal of Accounting and Economics, 60(2-3):65-96.

Efrat, A. and Newman, A. L. (2016). Deciding to defer: The importance of fairness in resolving transnational jurisdictional conflicts. International Organization, pages 409-441.

Eilstrup-Sangiovanni, M. and Sharman, J. (2019). Enforcers beyond borders: Transnational NGOs and the enforcement of international law. Perspectives on Politics. Forthcoming.

Escresa, L. and Picci, L. (2017). A new cross-national measure of corruption. The World Bank Economic Review, 31(1):196-219.

Farrell, H. and Newman, A. L. (2019). Weaponized interdependence: how global economic networks shape state coercion. International Security, 44(1):42-79.

Findley, M. G., Nielson, D. L., and Sharman, J. (2015). Causes of noncompliance with international law: A field experiment on anonymous incorporation. American Journal of Political Science, 59(1):146-161.

Fisman, R., Moustakerski, P., and Wei, S.-J. (2008). Outsourcing tariff evasion: A new explanation for entrepôt trade. The Review of Economics and Statistics, 90(3):587-592.

Garrett, B. L. (2011). Globalized corporate prosecutions. Virginia Law Review, 97:1775.

Garrett, B. L. (2014). Too Big to Jail: How Prosecutors Compromise with Corporations. Harvard University Press. 
Garrett, B. L. (2018). Individual and corporate criminals. In Research Handbook on Corporate Crime and Financial Misdealing. Edward Elgar Publishing.

Garrett, B. L. and Ashley, J. (2019). Corporate prosecution registry. Duke University and University of Virginia School of Law.

Genovese, F. (2020). Market responses to global governance: International climate cooperation and europe's carbon trading. Business and Politics, pages 1-33.

Gilbert, J.-A. and Sharman, J. C. (2016). Turning a blind eye to bribery: explaining failures to comply with the international anti-corruption regime. Political Studies, 64(1):74-89.

Gutterman, E. (2015). Easier done than said: Transnational bribery, norm resonance, and the origins of the US Foreign Corrupt Practices Act. Foreign Policy Analysis, 11(1):109-128.

Hafner-Burton, E. M. and Schneider, C. J. (2019). The dark side of cooperation: International organizations and member corruption. International Studies Quarterly, 63(4):1108-1121.

Jensen, N., Biglaiser, G., Li, Q., Malesky, E., Pinto, P., and Staats, J. (2012). Politics and foreign direct investment. University of Michigan Press.

Jensen, N. M. and Malesky, E. J. (2018). Nonstate actors and compliance with international agreements: An empirical analysis of the OECD Anti-Bribery Convention. International Organization, 72(1):33-69.

Kaczmarek, S. C. and Newman, A. L. (2011). The long arm of the law: Extraterritoriality and the national implementation of foreign bribery legislation. International Organization, 65(4):745-770.

Kalemli-Ozcan, S., Sorensen, B., Villegas-Sanchez, C., Volosovych, V., and Yesiltas, S. (2015). How to construct nationally representative firm level data from the Orbis global database: New facts and aggregate implications. Technical report, National Bureau of Economic Research.

Karpoff, J. M., Lee, D. S., and Martin, G. S. (2008). The cost to firms of cooking the books. Journal of financial and quantitative analysis, 43(3):581-611.

Keohane, R. O. (1984). After hegemony: Cooperation and discord in the world political economy. Princeton University Press.

Kerner, A. (2014). What we talk about when we talk about foreign direct investment. International Studies Quarterly, 58(4):804-815.

Kreitmeir, D., Lane, N., and Raschky, P. (2020). The value of names - civil society, information, and governing multinationals on the global periphery. Working paper. 
Krüger, P. (2015). Corporate goodness and shareholder wealth. Journal of Financial Economics, 115(2):304-329.

Leibold, A. (2014). Extraterritorial application of the FCPA under international law. Willamette Law Review, 51:225.

Lenz, G. and Sahn, A. (2020). Achieving statistical significance with control variables and without transparency. Political Analysis, pages 1-14.

Lin, W. (2013). Agnostic notes on regression adjustments to experimental data: Reexamining Freedman's critique. The Annals of Applied Statistics, 7(1):295-318.

Pierucci, F. (2019). The American Trap: My Battle to Expose America's Secret Economic War Against the Rest of the World. Hodder \& Stoughton.

Putnam, T. L. (2009). Courts without borders: Domestic sources of US extraterritoriality in the regulatory sphere. International Organization, pages 459-490.

Ruggie, J. G. (2018). Multinationals as global institution: Power, authority and relative autonomy. Regulation $\&$ Governance, 12(3):317-333.

Simmons, B. (2010). Treaty compliance and violation. Annual Review of Political Science, 13:273-296.

Slaughter, A.-M. (2004). Sovereignty and power in a networked world order. Stanford Journal of International Law, 40:283.

Strange, S. (1996). The Retreat of the State. The Diffusion of Power in the World Economy. Cambridge, UK: Cambridge University Press.

Thrall, C. (2021). Spillover effects in international law: The case of tax planning and investor-state dispute settlement. Working paper.

Tomashevskiy, A. (2021). Economic statecraft by other means: The use and abuse of anti-bribery prosecution. International Studies Quarterly.

Turk, M. C. (2012). A political economy approach to reforming the Foreign Corrupt Practices Act. Northwestern Journal of International Law $\&$ Business, 33:325.

Vogel, D. (1997). Trading up and governing across: transnational governance and environmental protection. Journal of European Public Policy, 4(4):556-571. 


\section{Appendix}

\section{Global Firms and Global Sheriffs. Why Territory Matters for Extraterritorial Enforcement of Regulatory Regimes}

\section{A Selection on observables design}

\section{A.1 Descriptive statistics}

Table A.1 reports descriptive statistics of variables included in the analysis. Investigation is a binary indicator for whether a company is ever investigated by the US in the TRACE Compendium or not. Investigation (share) measures the proportion of cases involving a company the US investigated from the TRACE Compendium. All other variables come from the Orbis Corporate Ownership Database. US Subsidiary is a binary indicator for whether a company has a majority-owned subsidiary in the US. US Subsidiary Employees $(\log +1)$ reports the natural logarithm of the count of employees in the US +1 for each company. Global Subsidiaries counts the number of majority-owned subsidiaries in the world for each company (expressed in thousands). Global Branches counts the number of branches in the world for each company (expressed in thousands). Global Employees $(\log +1)$ reports the natural lograithm of the count of employees in the world +1 for each company. Parent Revenues (mean) reports the average revenues for each parent company as available from Orbis in hundreds of billions of dollars. Parent Assets (mean) reports the average value of assets to each parent company as available from Orbis in hundreds of billions of dollars. Parent Employees (mean) reports the average number of employees to each parent company in hundreds of billions.

Table A.1: Bribe-payer non-US companies. Summary Statistics

\begin{tabular}{lrrrrrr}
\hline & $\mathrm{N}$ & Mean & SD & Min & Median & Max \\
\hline Investigation & 402 & 0.39 & 0.49 & 0.00 & 0.00 & 1.00 \\
Investigation (share) & 402 & 0.35 & 0.46 & 0.00 & 0.00 & 1.00 \\
US Subsidiary & 402 & 0.12 & 0.33 & 0.00 & 0.00 & 1.00 \\
US Subsidiary Employees (log +1$)$ & 402 & 1.06 & 2.90 & 0.00 & 0.00 & 11.36 \\
Global Subsidiaries & 402 & 0.01 & 0.03 & 0.00 & 0.00 & 0.21 \\
Global Branches & 402 & 0.02 & 0.16 & 0.00 & 0.00 & 2.16 \\
Global Employees (log+1) & 402 & 1.17 & 1.59 & 0.00 & 0.20 & 6.23 \\
Parent Revenues (mean) & 367 & 0.15 & 0.40 & 0.00 & 0.02 & 3.98 \\
Parent Assets (mean) & 349 & 0.71 & 2.80 & 0.00 & 0.04 & 26.12 \\
Parent Employees (mean) & 344 & 0.00 & 0.00 & 0.00 & 0.00 & 0.01 \\
\hline
\end{tabular}




\section{A.2 Robustness tests}

One potential reason of concern with the analysis comes from the different size of the treatment and control groups in my data. The dataset includes only 49 companies with at least one US subsidiary, whereas there are 353 firms with no US subsidiary (Table 1). OLS provide a variance-weighted estimate of the average treatment effect by using observable covariates to impute an untreated counterfactual for each treated unit and a treated counterfactual for each untreated unit (Aronow and Samii, 2016). In my case this latter endeavor might ask a lot to the data, as OLS try to use information on 49 treated companies to impute counterfactuals for 353 untreated units.

To tackle this concern, in my first robustness test I estimate a much narrower causal quantity: an average treatment effect on treated (ATT) units. This simply means using observable information on 353 untreated companies to impute counterfactuals for 49 treated firms. I estimate the ATT in two ways. First, I re-estimate models from Table 2 applying a regression imputation estimator as proposed by Lin (2013). The estimator is obtained by simply interacting the binary treatment variable with re-centred versions of the (numeric) covariates. The model removes the variance-weighting scheme OLS performs. Then, computing the marginal effect from this model with respect to treated units is a straightforward way to retrieve an estimate of the ATT.

Results obtained when applying this procedure are reported in Table A.2. Estimates of the ATT are consistent with the argument advanced. Models estimate that the probability of being investigated by the US increases of about $0.20-0.40$ for the 49 treated companies with respect to imputed units obtained from comparable untreated firms under observable features. Estimates are all distinguishable from zero at a 0.05 conventional level of significance.

Table A.2: Linear probability models of Investigation. Regression imputation estimator

\begin{tabular}{lccccc}
\hline & $(1)$ & $(2)$ & $(3)$ & $(4)$ & $(5)$ \\
\hline US Subsidiary & $\begin{array}{c}0.392^{* * *} \\
(0.076)\end{array}$ & $\begin{array}{c}0.465^{* * *} \\
(0.120)\end{array}$ & $\begin{array}{c}0.496^{* * *} \\
(0.119)\end{array}$ & $\begin{array}{c}0.570^{* * *} \\
(0.166)\end{array}$ & $\begin{array}{c}0.574^{* *} \\
(0.194)\end{array}$ \\
\hline Firm spread & & Yes & Yes & Yes & Yes \\
Parent size & & & Yes & Yes & Yes \\
Country FE & & & & Yes & Yes \\
Industry FE & & & & & Yes \\
ATT & $0.392^{* * *}$ & $0.315^{* * *}$ & $0.266^{* *}$ & $0.198^{*}$ & $0.208^{*}$ \\
& $(0.072)$ & $(0.086)$ & $(0.095)$ & $(0.096)$ & $(0.100)$ \\
Num.Obs. & 402 & 402 & 303 & 303 & 301 \\
R2 & 0.069 & 0.094 & 0.132 & 0.415 & 0.478 \\
R2 Adj. & 0.067 & 0.077 & 0.093 & 0.257 & 0.282 \\
$\mathrm{~F}$ & 29.678 & 5.812 & 3.370 & 2.634 & 2.437 \\
\hline$+\mathrm{p}<0.1, * \mathrm{p}<0.05, * *$ & $\mathrm{p}<0.01, * * *$ & $\mathrm{p}<0.001$ & &
\end{tabular}


Second, I re-estimate the same quantity adopting a matching procedure. I matched the 49 treated companies to 49 untreated companies. Matches were found using Mahalanobis distance according to the same covariates included in the full specification of model 2. I also performed bias adjustment for these very covariates as they are all numeric. I matched each treated observation to one untreated observation only, since increasing the number of matches even by one unit resulted in an unbalanced match. Figure A.1 reports the estimate of the ATT and the achieved balance in covariates. The estimate is consistent with the one presented earlier. The probability of being investigated by US authorities increases by about .30 for the 49 companies with investment in the US.

Figure A.1: Mahalanobis matching. ATT estimate and balance in covariates
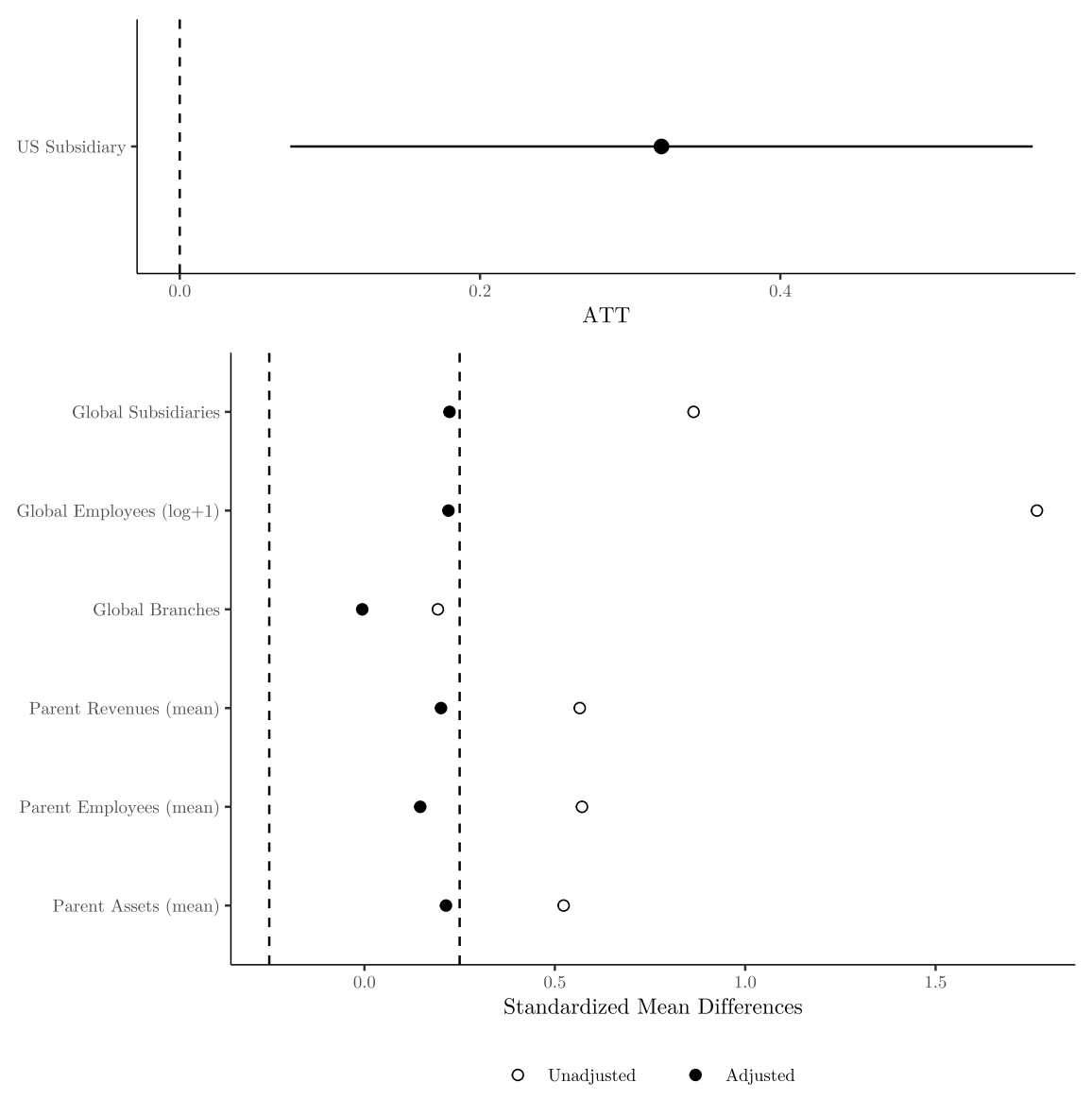
Next, I tackle the concern that OLS do not correctly model the distribution of my binary dependent variable. A LPM provides coefficients that represent differences in conditional means of the dependent variable, which are quantities of substantive interest. Yet, a binary dependent variable is more appropriately modelled using a logit model, where predicted values are constrained to range only between the values of 0 and 1. Table A.3 re-proposes models estimated above using this alternative functional form. Estimates are robust. Predicted probabilities inform us of very similar quantities as the ones documented earlier. In model 1, non-US companies with a US Subsidiary have a 0.73 probability of being investigated when they are involved in events of bribery. This is a substantive increase with respect to their counterparts with no presence in the US (predicted probability for this group: 0.34). Effect is very similar in the full specification of model 5 (increase in predicted probability from 0.42 to 0.80 ).

Table A.3: Logit models of Investigation. Binary main explanatory variable

\begin{tabular}{lccccc}
\hline & $(1)$ & $(2)$ & $(3)$ & $(4)$ & $(5)$ \\
\hline US Subsidiary & $1.670^{* * *}$ & $1.588^{* * *}$ & $1.455^{* *}$ & $1.619^{* *}$ & $1.722^{* *}$ \\
& $(0.376)$ & $(0.449)$ & $(0.473)$ & $(0.578)$ & $(0.548)$ \\
Global Subsidiaries & & -7.011 & -2.675 & 1.427 & 0.113 \\
& & $(5.718)$ & $(6.110)$ & $(8.247)$ & $(8.086)$ \\
Global Branches & & $13.921^{* *}$ & $12.555^{*}$ & $19.594^{* *}$ & $22.739^{* * *}$ \\
& & $(5.259)$ & $(5.161)$ & $(6.714)$ & $(6.542)$ \\
Global Employees (log+1) & & 0.091 & 0.045 & 0.022 & 0.176 \\
& & $(0.105)$ & $(0.124)$ & $(0.141)$ & $(0.152)$ \\
Parent Revenues (mean) & & & 0.388 & 0.232 & -0.380 \\
& & & $(0.637)$ & $(0.848)$ & $(1.056)$ \\
Parent Assets (mean) & & & $(0.157+$ & $0.271^{*}$ & 0.312 \\
& & & $-391.866+$ & $-403.134)$ & $(0.212)$ \\
Parent Employees (mean) & & & $(204.251)$ & $(198.145)$ & -422.528 \\
& & & & Yes & Yes \\
Country FE & 402 & 402 & 303 & 303 & Yes \\
Industry FE & 514.6 & 501.8 & 383.9 & 376.7 & 301 \\
Num.Obs. & 522.5 & 521.8 & 413.6 & 595.8 & 663.1 \\
AIC & -255.278 & -245.909 & -183.949 & -129.343 & -111.822 \\
BIC & & & & \\
Log.Lik. & & & &
\end{tabular}


The inclusion of home country and industry fixed-effects removes heterogeneity at this level, but only allows to study variation within each category of these variables. Random effects provide a more flexible way of modelling multilevel heterogeneity (Bell and Jones, 2015). I re-estimate models 4 and 5 from Table 2 using random intercepts at the home country and industry-level in a multilevel linear and multilevel logit model. Results are robust to these model choices (Table A.4).

Table A.4: Multilevel models of Investigation. Binary main explanatory variable

\begin{tabular}{|c|c|c|c|c|}
\hline & \multicolumn{2}{|c|}{ Multilevel linear } & \multicolumn{2}{|c|}{ Multilevel logit } \\
\hline & (1) & $(2)$ & $(3)$ & $(4)$ \\
\hline \multirow[t]{2}{*}{ US Subsidiary } & $0.268^{* *}$ & $0.276^{* *}$ & $1.528^{* *}$ & $1.616^{* *}$ \\
\hline & $(0.085)$ & $(0.085)$ & $(0.488)$ & $(0.532)$ \\
\hline \multirow[t]{2}{*}{ Global Subsidiaries } & 0.140 & 0.151 & 0.124 & -0.122 \\
\hline & $(1.256)$ & $(1.241)$ & $(7.802)$ & $(9.243)$ \\
\hline \multirow[t]{2}{*}{ Global Branches } & 0.261 & 0.242 & $16.317^{*}$ & $17.600^{*}$ \\
\hline & $(0.161)$ & $(0.161)$ & $(7.079)$ & $(7.398)$ \\
\hline \multirow[t]{2}{*}{ Global Employees $(\log +1)$} & 0.022 & 0.030 & 0.050 & 0.095 \\
\hline & $(0.027)$ & $(0.027)$ & $(0.155)$ & $(0.186)$ \\
\hline \multirow[t]{2}{*}{ Parent Revenues (mean) } & $0.186^{*}$ & $0.153+$ & 0.489 & 0.250 \\
\hline & $(0.090)$ & $(0.091)$ & $(0.770)$ & $(1.377)$ \\
\hline \multirow[t]{2}{*}{ Parent Assets (mean) } & 0.013 & 0.013 & 0.192 & 0.203 \\
\hline & $(0.011)$ & $(0.011)$ & $(0.127)$ & $(0.139)$ \\
\hline \multirow[t]{2}{*}{ Parent Employees (mean) } & $-78.745+$ & $-78.636+$ & -418.028 & -408.350 \\
\hline & $(41.055)$ & $(41.131)$ & $(404.100)$ & $(988.394)$ \\
\hline \multirow[t]{2}{*}{ (Intercept) } & $0.366^{* * *}$ & $0.356^{* * *}$ & -0.449 & -0.515 \\
\hline & $(0.046)$ & $(0.053)$ & $(0.277)$ & $(0.318)$ \\
\hline Country RE & Yes & Yes & Yes & Yes \\
\hline Industry RE & & Yes & & Yes \\
\hline Num.Obs. & 303 & 301 & 303 & 301 \\
\hline $\mathrm{AIC}$ & 408.9 & 405.2 & 366.0 & 362.9 \\
\hline $\mathrm{BIC}$ & 446.0 & 446.0 & 399.4 & 400.0 \\
\hline
\end{tabular}


Next, I study the share of cases investigated by the US for each company in the dataset (Investigation Share). I replicate the same model choices as in Table 2 in a linear model estimated using OLS. Results inform us that US authorities on average investigated between 0.20 and 0.30 more of the total cases involving companies with a subsidiary in the country (Table A.5).

Table A.5: Linear models of Investigation Share. Binary main explanatory variable

\begin{tabular}{lccccc}
\hline & $(1)$ & $(2)$ & $(3)$ & $(4)$ & $(5)$ \\
\hline US Subsidiary & $0.304^{* * *}$ & $0.279^{* * *}$ & $0.260^{* *}$ & $0.199^{*}$ & $0.219^{* *}$ \\
& $(0.067)$ & $(0.082)$ & $(0.092)$ & $(0.097)$ & $(0.081)$ \\
Global Subsidiaries & & -1.300 & -0.851 & 0.073 & 0.117 \\
& & $(0.896)$ & $(1.007)$ & $(1.032)$ & $(0.849)$ \\
Global Branches & & $0.386^{* * *}$ & $0.269+$ & $0.253^{* * *}$ & $0.230^{* *}$ \\
& & $(0.106)$ & $(0.141)$ & $(0.075)$ & $(0.085)$ \\
Global Employees (log+1) & & 0.018 & 0.004 & 0.003 & 0.021 \\
& & $(0.024)$ & $(0.029)$ & $(0.025)$ & $(0.028)$ \\
Parent Revenues (mean) & & & 0.077 & 0.101 & 0.026 \\
& & & $(0.065)$ & $(0.073)$ & $(0.129)$ \\
Parent Assets (mean) & & & $0.015+$ & $0.020^{* * *}$ & $0.018^{* *}$ \\
& & & $-43.757^{* *}$ & -44.573 & -43.409 \\
Parent Employees (mean) & & & $(16.481)$ & $(28.307)$ & $(72.602)$ \\
& & & & & \\
Intercept) & $0.312^{* * *}$ & $0.301^{* * *}$ & $0.326^{* * *}$ & 0.000 & $-0.394^{*}$ \\
& $(0.040)$ & $(0.044)$ & $(0.057)$ & $(0.063)$ & $(0.170)$ \\
\hline Country FE & & & & Yes & Yes \\
Industry FE & & & & & Yes \\
Num.Obs. & 402 & 402 & 303 & 303 & 301 \\
R2 & 0.048 & 0.068 & 0.087 & 0.399 & 0.467 \\
R2 Adj. & 0.045 & 0.059 & 0.065 & 0.257 & 0.286 \\
F & 19.949 & 7.229 & 3.996 & 2.797 & 2.582 \\
\hline
\end{tabular}


Finally, I use an alternative explanatory variable measuring the presence of a company in the US economy. I measure the number of employees of each company through US subsidiaries and take the logarithm of the measure +1 . I replicate my model specifications of Investigation using this alternative explanatory variable and present results obtained from a LPM (Table A.6). Estimates inform us that a one unit increase in the logarithm of the number of US employees (hence, about a $+1 \%$ in the number of US employees) increases the probability of investigation by the US by about $3 \%$ to $4 \%$. Estimates are distinguishable from zero at a 0.05 conventional level of significance. These latter estimates are robust when using a logit model (Table A.7), random-effect models (Table A.8), and a continuous version of the dependent variable (Table A.9).

Table A.6: Linear probability models of Investigation. Continuous main explanatory variable

\begin{tabular}{|c|c|c|c|c|c|}
\hline & (1) & $(2)$ & $(3)$ & (4) & $(5)$ \\
\hline US Subsidiary Employees $(\log +1)$ & $\begin{array}{c}0.044^{* * *} \\
(0.008)\end{array}$ & $\begin{array}{c}0.036^{* * *} \\
(0.010)\end{array}$ & $\begin{array}{c}0.034^{* *} \\
(0.011)\end{array}$ & $\begin{array}{l}0.028^{*} \\
(0.012)\end{array}$ & $\begin{array}{l}0.028^{*} \\
(0.012)\end{array}$ \\
\hline Global Subsidiaries & & $\begin{array}{l}-0.959 \\
(0.814)\end{array}$ & $\begin{array}{l}-0.760 \\
(1.040)\end{array}$ & $\begin{array}{c}0.493 \\
(1.153)\end{array}$ & $\begin{array}{c}0.411 \\
(1.032)\end{array}$ \\
\hline Global Branches & & $\begin{array}{c}0.349^{* *} \\
(0.129)\end{array}$ & $\begin{array}{l}0.275^{*} \\
(0.134)\end{array}$ & $\begin{array}{c}0.221^{* *} \\
(0.072)\end{array}$ & $\begin{array}{c}0.169 \\
(0.113)\end{array}$ \\
\hline Global Employees $(\log +1)$ & & $\begin{array}{c}0.030 \\
(0.022)\end{array}$ & $\begin{array}{c}0.022 \\
(0.028)\end{array}$ & $\begin{array}{c}0.014 \\
(0.027)\end{array}$ & $\begin{array}{c}0.037 \\
(0.033)\end{array}$ \\
\hline Parent Revenues (mean) & & & $\begin{array}{l}0.175^{*} \\
(0.079)\end{array}$ & $\begin{array}{l}0.197^{*} \\
(0.096)\end{array}$ & $\begin{array}{c}0.118 \\
(0.141)\end{array}$ \\
\hline Parent Assets (mean) & & & $\begin{array}{c}0.009 \\
(0.007)\end{array}$ & $\begin{array}{c}0.016^{* *} \\
(0.006)\end{array}$ & $\begin{array}{l}0.016^{*} \\
(0.008)\end{array}$ \\
\hline Parent Employees (mean) & & & $\begin{array}{c}-75.253^{* * *} \\
(18.410)\end{array}$ & $\begin{array}{c}-81.906 * \\
(35.394)\end{array}$ & $\begin{array}{l}-81.790 \\
(74.532)\end{array}$ \\
\hline (Intercept) & $\begin{array}{c}0.345^{* * *} \\
(0.041)\end{array}$ & $\begin{array}{c}0.322^{* * *} \\
(0.048)\end{array}$ & $\begin{array}{c}0.341^{* * *} \\
(0.059)\end{array}$ & $\begin{array}{l}-0.027 \\
(0.067)\end{array}$ & $\begin{array}{c}-0.339+ \\
(0.178)\end{array}$ \\
\hline Country FE & & & & Yes & Yes \\
\hline Industry FE & & & & & Yes \\
\hline Num.Obs. & 402 & 402 & 303 & 303 & 301 \\
\hline $\mathrm{R} 2$ & 0.067 & 0.084 & 0.107 & 0.384 & 0.447 \\
\hline R2 Adj. & 0.064 & 0.075 & 0.086 & 0.238 & 0.260 \\
\hline $\mathrm{F}$ & 28.557 & 9.092 & 5.045 & 2.623 & 2.387 \\
\hline
\end{tabular}

$+\mathrm{p}<0.1,{ }^{*} \mathrm{p}<0.05,{ }^{* *} \mathrm{p}<0.01,{ }^{* * *} \mathrm{p}<0.001$ 
Table A.7: Logit models of Investigation. Continuous main explanatory variable

\begin{tabular}{|c|c|c|c|c|c|}
\hline & (1) & $(2)$ & (3) & (4) & $(5)$ \\
\hline US Subsidiary Employees $(\log +1)$ & $\begin{array}{c}0.187^{* * *} \\
(0.042)\end{array}$ & $\begin{array}{c}0.177^{* * *} \\
(0.052)\end{array}$ & $\begin{array}{c}0.163^{* *} \\
(0.057)\end{array}$ & $\begin{array}{c}0.177^{*} \\
(0.069)\end{array}$ & $\begin{array}{c}0.179^{* *} \\
(0.066)\end{array}$ \\
\hline Global Subsidiaries & & $\begin{array}{l}-6.769 \\
(5.772)\end{array}$ & $\begin{array}{l}-2.944 \\
(6.284)\end{array}$ & $\begin{array}{c}1.008 \\
(8.001)\end{array}$ & $\begin{array}{c}-0.652 \\
(7.813)\end{array}$ \\
\hline Global Branches & & $\begin{array}{c}13.760^{* *} \\
(5.293)\end{array}$ & $\begin{array}{c}12.240^{*} \\
(5.310)\end{array}$ & $\begin{array}{c}18.639^{* *} \\
(6.860)\end{array}$ & $\begin{array}{c}21.696^{* *} \\
(6.713)\end{array}$ \\
\hline Global Employees $(\log +1)$ & & $\begin{array}{c}0.089 \\
(0.108)\end{array}$ & $\begin{array}{c}0.038 \\
(0.127)\end{array}$ & $\begin{array}{c}0.020 \\
(0.140)\end{array}$ & $\begin{array}{c}0.173 \\
(0.156)\end{array}$ \\
\hline Parent Revenues (mean) & & & $\begin{array}{c}0.519 \\
(0.638)\end{array}$ & $\begin{array}{c}0.406 \\
(0.827)\end{array}$ & $\begin{array}{l}-0.172 \\
(1.008)\end{array}$ \\
\hline Parent Assets (mean) & & & $\begin{array}{c}0.152 \\
(0.093)\end{array}$ & $\begin{array}{l}0.259+ \\
(0.138)\end{array}$ & $\begin{array}{c}0.300 \\
(0.209)\end{array}$ \\
\hline Parent Employees (mean) & & & $\begin{array}{r}-403.956+ \\
(214.571)\end{array}$ & $\begin{array}{r}-408.173+ \\
(215.329)\end{array}$ & $\begin{array}{l}-406.029 \\
(418.825)\end{array}$ \\
\hline Country FE & & & & Yes & Yes \\
\hline Industry FE & & & & & Yes \\
\hline Num.Obs. & 402 & 402 & 303 & 303 & 301 \\
\hline AIC & 515.4 & 503.0 & 384.9 & 378.2 & 379.6 \\
\hline $\mathrm{BIC}$ & 523.4 & 523.0 & 414.6 & 597.3 & 665.1 \\
\hline Log.Lik. & -255.703 & -246.496 & -184.451 & -130.118 & -112.824 \\
\hline
\end{tabular}


Table A.8: Multilevel models of Investigation. Continuous main explanatory variable

\begin{tabular}{|c|c|c|c|c|}
\hline & \multicolumn{2}{|c|}{ Multilevel linear } & \multicolumn{2}{|c|}{ Multilevel logit } \\
\hline & $(1)$ & $(2)$ & $(3)$ & $(4)$ \\
\hline US Subsidiary Employees $(\log +1)$ & $\begin{array}{l}0.026^{*} \\
(0.010)\end{array}$ & $\begin{array}{c}0.027^{* *} \\
(0.010)\end{array}$ & $\begin{array}{c}0.147^{*} \\
(0.059)\end{array}$ & $\begin{array}{l}0.156^{*} \\
(0.062)\end{array}$ \\
\hline Global Subsidiaries & $\begin{array}{l}-1.121 \\
(1.720)\end{array}$ & $\begin{array}{l}-1.266 \\
(1.708)\end{array}$ & $\begin{array}{c}-8.377 \\
(10.266)\end{array}$ & $\begin{array}{c}-9.364 \\
(11.190)\end{array}$ \\
\hline Global Branches & $\begin{array}{c}0.238 \\
(0.163)\end{array}$ & $\begin{array}{c}0.216 \\
(0.162)\end{array}$ & $\begin{array}{c}16.556^{*} \\
(7.380)\end{array}$ & $\begin{array}{c}17.630^{*} \\
(7.700)\end{array}$ \\
\hline Total Host Countries & $\begin{array}{c}0.007 \\
(0.007)\end{array}$ & $\begin{array}{c}0.008 \\
(0.007)\end{array}$ & $\begin{array}{c}0.048 \\
(0.040)\end{array}$ & $\begin{array}{c}0.052 \\
(0.042)\end{array}$ \\
\hline Global Employees $(\log +1)$ & $\begin{array}{c}0.008 \\
(0.030)\end{array}$ & $\begin{array}{c}0.014 \\
(0.030)\end{array}$ & $\begin{array}{l}-0.045 \\
(0.171)\end{array}$ & $\begin{array}{l}-0.010 \\
(0.191)\end{array}$ \\
\hline Parent Revenues (mean) & $\begin{array}{l}0.215^{*} \\
(0.091)\end{array}$ & $\begin{array}{c}0.183^{*} \\
(0.092)\end{array}$ & $\begin{array}{c}0.744 \\
(0.640)\end{array}$ & $\begin{array}{c}0.533 \\
(1.043)\end{array}$ \\
\hline Parent Assets (mean) & $\begin{array}{c}0.014 \\
(0.011)\end{array}$ & $\begin{array}{c}0.014 \\
(0.011)\end{array}$ & $\begin{array}{c}0.195 \\
(0.125)\end{array}$ & $\begin{array}{c}0.202 \\
(0.135)\end{array}$ \\
\hline Parent Employees (mean) & $\begin{array}{r}-76.366+ \\
(41.333)\end{array}$ & $\begin{array}{r}-74.889+ \\
(41.490)\end{array}$ & $\begin{array}{r}-410.905+ \\
(218.819)\end{array}$ & $\begin{array}{l}-391.465 \\
(667.074)\end{array}$ \\
\hline (Intercept) & $\begin{array}{c}0.373^{* * *} \\
(0.047)\end{array}$ & $\begin{array}{c}0.363^{* * *} \\
(0.053)\end{array}$ & $\begin{array}{l}-0.395 \\
(0.279)\end{array}$ & $\begin{array}{l}-0.460 \\
(0.319)\end{array}$ \\
\hline Country RE & Yes & Yes & Yes & Yes \\
\hline Industry RE & & Yes & & Yes \\
\hline Num.Obs. & 303 & 301 & 303 & 301 \\
\hline $\mathrm{AIC}$ & 423.6 & 419.8 & 368.0 & 364.9 \\
\hline $\mathrm{BIC}$ & 464.5 & 464.3 & 405.1 & 405.7 \\
\hline
\end{tabular}


Table A.9: Linear models of Investigation Share. Continuous main explanatory variable

\begin{tabular}{|c|c|c|c|c|c|}
\hline & (1) & (2) & (3) & (4) & $(5)$ \\
\hline US Subsidiary Employees $(\log +1)$ & $\begin{array}{c}0.034^{* * *} \\
(0.007)\end{array}$ & $\begin{array}{c}0.031^{* *} \\
(0.009)\end{array}$ & $\begin{array}{c}0.029^{* *} \\
(0.011)\end{array}$ & $\begin{array}{l}0.021+ \\
(0.011)\end{array}$ & $\begin{array}{l}0.022^{*} \\
(0.010)\end{array}$ \\
\hline Global Subsidiaries & & $\begin{array}{l}-1.271 \\
(0.878)\end{array}$ & $\begin{array}{l}-0.871 \\
(1.015)\end{array}$ & $\begin{array}{c}0.042 \\
(1.022)\end{array}$ & $\begin{array}{c}0.074 \\
(0.845)\end{array}$ \\
\hline Global Branches & & $\begin{array}{c}0.379 * * * \\
(0.109)\end{array}$ & $\begin{array}{l}0.268+ \\
(0.142)\end{array}$ & $\begin{array}{c}0.250^{* *} \\
(0.077)\end{array}$ & $\begin{array}{l}0.227^{*} \\
(0.087)\end{array}$ \\
\hline Global Employees $(\log +1)$ & & $\begin{array}{c}0.017 \\
(0.024)\end{array}$ & $\begin{array}{c}0.003 \\
(0.029)\end{array}$ & $\begin{array}{c}0.003 \\
(0.025)\end{array}$ & $\begin{array}{c}0.021 \\
(0.029)\end{array}$ \\
\hline Parent Revenues (mean) & & & $\begin{array}{c}0.092 \\
(0.067)\end{array}$ & $\begin{array}{c}0.112 \\
(0.072)\end{array}$ & $\begin{array}{c}0.038 \\
(0.125)\end{array}$ \\
\hline Parent Assets (mean) & & & $\begin{array}{l}0.014+ \\
(0.008)\end{array}$ & $\begin{array}{c}0.020^{* * *} * \\
(0.006)\end{array}$ & $\begin{array}{l}0.019^{* *} \\
(0.007)\end{array}$ \\
\hline Parent Employees (mean) & & & $\begin{array}{c}-44.851^{* *} \\
(16.911)\end{array}$ & $\begin{array}{l}-45.906 \\
(29.641)\end{array}$ & $\begin{array}{l}-45.031 \\
(74.731)\end{array}$ \\
\hline (Intercept) & $\begin{array}{c}0.313^{* * *} \\
(0.040)\end{array}$ & $\begin{array}{c}0.303^{* * *} \\
(0.044)\end{array}$ & $\begin{array}{c}0.328^{* * *} \\
(0.057)\end{array}$ & $\begin{array}{l}-0.001 \\
(0.063)\end{array}$ & $\begin{array}{l}-0.388^{*} \\
(0.171)\end{array}$ \\
\hline Country FE & & & & Yes & Yes \\
\hline Industry FE & & & & & Yes \\
\hline Num.Obs. & 402 & 402 & 303 & 303 & 301 \\
\hline $\mathrm{R} 2$ & 0.046 & 0.066 & 0.084 & 0.396 & 0.463 \\
\hline R2 Adj. & 0.044 & 0.056 & 0.063 & 0.252 & 0.280 \\
\hline $\mathrm{F}$ & 19.322 & 6.973 & 3.879 & 2.757 & 2.539 \\
\hline
\end{tabular}

$+\mathrm{p}<0.1,{ }^{*} \mathrm{p}<0.05,{ }^{* *} \mathrm{p}<0.01,{ }^{* * *} \mathrm{p}<0.001$ 